Article

\title{
Optimization of Biochar Production by Co-Torrefaction of Microalgae and Lignocellulosic Biomass Using Response Surface Methodology
}

\author{
Catarina Viegas $^{1, *(\mathbb{C})}$, Catarina Nobre ${ }^{2}$, Ricardo Correia ${ }^{1}\left(\mathbb{D}\right.$, Luísa Gouveia $^{3}(\mathbb{1})$ and Margarida Gonçalves ${ }^{1}(\mathbb{C}$ \\ 1 MEtRICs-Mechanical Engineering and Resource Sustainability Center, Department of Science and \\ Technology of Biomass, Faculdade de Ciências e Tecnologia da Universidade NOVA de Lisboa (FCT-NOVA), \\ Campus de Caparica, 2829-516 Caparica, Portugal; rjc07189@campus.fct.unl.pt (R.C.); \\ mmpg@fct.unl.pt (M.G.) \\ 2 CoLAB BIOREF-Collaborative Laboratory for Biorefineries, Rua Amieira Apartado 1089, \\ 4466-901 São Mamede de Infesta, Portugal; catarina-nobre@bioref-colab.pt \\ 3 LNEG-Laboratório Nacional de Energia e Geologia, I.P./Bioenergy Unit, Estrada do Paço do Lumiar 22, \\ 1649-038 Lisbon, Portugal; luisa.gouveia@lneg.pt \\ * Correspondence: cv.sousa@campus.fct.unl.pt
}

check for updates

Citation: Viegas, C.; Nobre, C.; Correia, R.; Gouveia, L.; Gonçalves, M. Optimization of Biochar Production by Co-Torrefaction of Microalgae and Lignocellulosic Biomass Using Response Surface Methodology. Energies 2021, 14, 7330. https:// doi.org/10.3390/en14217330

Academic Editor: Michael Pohořelý

Received: 13 October 2021

Accepted: 2 November 2021

Published: 4 November 2021

Publisher's Note: MDPI stays neutral with regard to jurisdictional claims in published maps and institutional affiliations.

Copyright: (c) 2021 by the authors. Licensee MDPI, Basel, Switzerland. This article is an open access article distributed under the terms and conditions of the Creative Commons Attribution (CC BY) license (https:// creativecommons.org/licenses/by/ $4.0 /)$.

\begin{abstract}
Co-torrefaction of microalgae and lignocellulosic biomass was evaluated as a method to process microalgae sludge produced from various effluents and to obtain biochars with suitable properties for energy or material valorization. The influence of four independent variables on biochar yield and properties was evaluated by a set of experiments defined by response surface methodology (RSM). The biochars were characterized for proximate and ultimate composition, HHV, and methylene blue adsorption capacity. HHV of the biochars was positively correlated with carbonization temperature, residence time, and lignocellulosic biomass content in the feed. Co-torrefaction conditions that led to a higher yield of biochar (76.5\%) with good calorific value (17.4 MJ Kg ${ }^{-1}$ ) were $250{ }^{\circ} \mathrm{C}, 60 \mathrm{~min}$ of residence time, $5 \%$ feed moisture, and 50\% lignocellulosic biomass. The energy efficiency of the process was higher for lower temperatures $(92.6 \%)$ but decreased abruptly with the increase of the moisture content of the feed mixture (16.9 to $57.3 \%$ for $70 \%$ moisture). Biochars produced using algal biomass grown in contaminated effluents presented high ash content and low calorific value. Dye removal efficiency by the produced biochars was tested, reaching 95\% methylene blue adsorption capacity for the biochars produced with the least severe torrefaction conditions.
\end{abstract}

Keywords: Chlorella vulgaris; lignocellulosic biomass; biochar; torrefaction; carbonization; RSM

\section{Introduction}

Microalgae are efficient agents for the bioremediation of animal production effluents due to their high capacity to remove nitrogen and phosphorus, two important contributors to the chemical oxygen demand (COD) of such effluents [1-3]. The robustness of microalgae makes them suitable to treat recalcitrant effluents with high levels of organic or inorganic contaminants, that are difficult to remediate with aerobic or anaerobic bacteria [3-5]. After bioremediation, the algal biomass must be separated from the treated effluent and ideally valorized as raw material for fuels and/or specialty chemicals. Separation of the algal biomass has been studied using membrane technology [6], electrocoagulation [7,8], radiofrequency [9], and coagulation with polymers [10], but these techniques involve complex equipment and additional costs that are compatible only with large scale systems with the subsequent valorization of the algal biomass in multiple applications. A possible alternative is the decantation of the sedimented biomass, in the form of an algal sludge that can be further dried or mixed with other biomass feedstocks to be used in energy or material applications. For example, mixing wet algal biomass (80\% moisture) with yard 
waste has been proposed as a stabilization technique to preserve the algal biomass and avoid or facilitate the drying step [11].

On the other hand, microalgae produced in contaminated effluents are not suitable for food applications; therefore, alternative valorization pathways such as energy conversion processes have been suggested in the literature [12-14]. Microalgae can be grown in conditions that maximize their lipid or carbohydrate contents, and after isolation of those components, they may be converted to hydrocarbon or alcohol biofuels $[15,16]$. More recently the processes of integral conversion of algal biomass, namely through fermentation [17], anaerobic digestion [18], hydrothermal liquefaction [19,20], pyrolysis, or gasification [19,21], have also been evaluated as alternative processing technologies for algal biomass. By using these biological or thermochemical processes, the algal biomass is converted to gas or liquid products with a high calorific value that may be used as fuels either directly or after upgrading. The use of algal biomass in these conversion processes also contributes to their sustainability by diversifying the feedstocks.

Torrefaction is a thermochemical process that applies moderate pyrolysis conditions, with temperatures between 200 and $320^{\circ} \mathrm{C}$, under an inert atmosphere. It is an effective process of upgrading biomass by removing moisture and reducing the content of the volatile components, while promoting chemical reactions that involve the constituting polymers [22,23]. This process results in densification of the torrefied material, an increase in its heating value and carbon content, and a decrease of its $\mathrm{H} / \mathrm{C}$ and $\mathrm{O} / \mathrm{C}$ atomic ratios, reinforcing its hydrophobic nature $[24,25]$. Depending on the specific torrefaction conditions, namely, temperature and residence time, different yields of biochar, condensates, and gas products will be obtained. The composition of the raw material also greatly influences the composition and relative concentrations of the torrefaction products [26]. Thermochemical co-processing of different biomass feedstocks allows for bio-oils and biochars with specific characteristics to be obtained, different from those obtained when processing the individual materials [27-29]. Torrefaction has already been tested for several biomass feedstocks. The use of microalgae is a very promising option, especially if algal biomass is obtained through the remediation of residual effluents $[15,26]$. For instance, the torrefaction of several microalgae (Chlamydomonas sp., Scenedesmus obliquus, Chlorella sorokiniana, and Chlorella vulgaris) at temperatures between 200 and $300{ }^{\circ} \mathrm{C}$ for 15 to $60 \mathrm{~min}$, was carried out by several authors aiming to evaluate the influence of the conversion conditions on the biochar yield and properties. High biochar yields (86-91\%) were obtained at $200{ }^{\circ} \mathrm{C}$ and $1 \mathrm{~h}$, while at $300{ }^{\circ} \mathrm{C}$ and $1 \mathrm{~h}$ the biochar yield was strongly dependent on the type of microalgae used, with values of $38 \%$ for Chlorella sorokiniana [30], 41\% for Chlamydomonas sp. [30], 53\% for Chlorella vulgaris [31], and 63\% for Scenedesmus obliquus [32].

The combination of algal biomass with other materials or biomass residues has also been addressed by some authors who have studied co-pelletization of Chlorella vulgaris biomass with pine sawdust [12], co-carbonization of coal mixed with algae in different proportions [33], and co-liquefaction of Tetraselmis sp. biomass in the presence of ethylene glycol or isopropyl alcohol [34]. The co-liquefaction of microalgae Chlorella pyrenoidosa and rice husk in subcritical water showed synergistic effects that decreased the acidity and nitrogen content of bio-crude oils [35].

The choice of the torrefaction technology mostly relates to its less demanding energy features when compared to other thermal processes [36]. In addition, the main product obtained in torrefaction is a char that can be used directly in various energy or material applications without requiring further processing, as is the case of pyrolysis bio-oil, which usually requires upgrading treatments [27,35]. Hydrothermal carbonization (HTC) also produces a biochar that can be used as a fuel, as an activated carbon, or as a fertilizer for soil correction and amendment. However, the HTC process also produces high volumes of a liquid phase that must be treated or valorized to decrease costs and increase the sustainability of this technology. Furthermore, scaling up the HTC technology requires expensive high-pressure reactors and accessory equipment capable of withstanding corrosive media $[37,38]$. 
This study intends to evaluate the co-torrefaction of microalgae sludge with lignocellulosic biomass as a simple and low-cost technology to process algal sludges obtained from the bioremediation of industrial or agro-industrial effluents. The co-torrefaction process was also selected as a technology to promote the elimination of nitrogen, therefore improving the fuel quality of algal biomass by decreasing its potential to generate NOx emissions. Nitrogen is eliminated during devolatilization and char conversion processes [39]. The influence of process parameters (carbonization temperature, residence time, concentration of lignocellulosic biomass in the feed, and the moisture of the feed) in the yields of carbonization products and properties of the biochars were studied using a series of experiments defined by RSM (response surface methodology). Moreover, this work also tested the co-torrefaction of microalgae used in the bioremediation of an aquaculture effluent and a landfill leachate as examples of real case scenarios and provides insights on the use of the produced biochars as low-cost adsorbents.

\section{Materials and Methods}

\subsection{Biomass Feedstocks Characterization}

Microalgal biomass $(\mathrm{Cv})$ and lignocellulosic material $(\mathrm{Lc})$ were used as raw materials in this study. The Cv sample corresponded to dried Chlorella vulgaris biomass obtained from a commercial source (Allmicroalgae-Natural Products S.A.). The Lc sample was composed of waste pine biomass used for pellet production and was supplied by CMC Biomassa. The Lc sample was further milled in a coffee grinder (Bosch TSM6A011W) and sieved by a 10 mesh $(=2 \mathrm{~mm})$ sieve. Both biomasses were oven-dried until a moisture content of 5\% was achieved. Proximate analysis of ash content (Ash), volatile matter (VM), and moisture $(\mathrm{MC})$ was determined gravimetrically, for both biomass materials, according to the methods described in BS EN 15403:2011, 942-2007, and ISO 665:2020, respectively. Fixed carbon (FC) was determined by difference in a dry basis (db). Ultimate analysis (carbon, hydrogen, nitrogen, and sulfur contents) was performed using an elemental analyzer (Thermo Finnigan-CE Instruments Model Flash EA 112 CHNS series). Oxygen content was determined by difference on a dry ash free basis (daf).

High heating values (HHV) of the feedstocks were calculated using a correlation established by Huang and Lo [40] based on elemental composition data:

$$
\text { HHV }\left(\mathrm{MJ} \cdot \mathrm{kg}^{-1}, \mathrm{db}\right)=0.3443 \mathrm{C}+1.192 \mathrm{H}-0.113 \mathrm{O}-0.024 \mathrm{~N}+0.093 \mathrm{~S}
$$

After process optimization, microalgae biomass obtained from the remediation of an aquaculture effluent [4] and a landfill leachate [3] were subjected to the co-torrefaction process with lignocellulosic material $(0,50$, and $100 \%)$ at $250{ }^{\circ} \mathrm{C}$ and $60 \mathrm{~min}$, without water addition, that is, with $5 \%$ feed moisture. The aquaculture microalgae biomass was produced over 34 days in $1.5 \mathrm{~L}$ reactors using un effluent with $9600 \mathrm{mg} \mathrm{O}_{2} \mathrm{~L}^{-1}$ of COD, $3266 \mathrm{mg} \mathrm{N} \mathrm{L}^{-1}$, and $23 \mathrm{mg} \mathrm{P} \mathrm{L}^{-1}$ and reaching biomass productivity of $880 \mathrm{mg} \mathrm{L}^{-1} \mathrm{~d}^{-1}$. The landfill leachate microalgae biomass was produced over 27 days in $2 \mathrm{~L}$ reactors using un effluent with $5200 \mathrm{mg} \mathrm{O}_{2} \mathrm{~L}^{-1}$ of COD, $738 \mathrm{mg} \mathrm{N} \mathrm{L}^{-1}$, and $22 \mathrm{mg} \mathrm{P} \mathrm{L}^{-1}$ (pretreated with biomass ash) and reaching a biomass productivity of $40 \mathrm{mg} \mathrm{L}^{-1} \mathrm{~d}^{-1}$. Biochars obtained in the experiments with microalgae produced in aquaculture wastewater and landfill leachate were analyzed following the same methodology used for biochars obtained with commercial dry microalgae (Section 2.4).

\subsection{Torrefaction Experiments}

The torrefaction tests were performed on a glass reactor placed in a gas chromatography furnace (Thermo Finnigan Trace GC with FID), under oxygen-limited conditions, as described by Şen et al. [41]. For each experiment, selected masses of dry algal biomass, lignocellulosic material, and added water were introduced in the reactor in order to achieve the values of Lc incorporation rate and feed moisture defined in the experimental design, as shown in Table S1 (Supplementary Materials). A total of 39 initial compositions were considered, with incorporations of $0,25,50,75$, and $100 \%$ of lignocellulosic material and 
feed moisture contents of $5,15,30,45$, and $70 \%$. The samples were placed in $250 \mathrm{~mL}$ glass flasks and heated up to the final torrefaction temperatures $\left(200,225,250,275\right.$, or $\left.300{ }^{\circ} \mathrm{C}\right)$ while the conditions were kept isothermal for $15,30,45$, or $60 \mathrm{~min}$. In the end, the furnace was cooled to $35^{\circ} \mathrm{C}$, with a cooling rate equal to the heating rate that varied between 11 and $14^{\circ} \mathrm{C} / \mathrm{min}$.

The liquid phase was collected in a cooling trap and the mass yields of biochar and liquid phase were determined with an analytical scale (Mettler Toledo AB204-S). The gas yield was determined by difference. Biochar samples were stored in dry conditions until further analysis and liquid phase samples were stored at $-4{ }^{\circ} \mathrm{C}$ to avoid chemical and biological degradation.

\subsection{Torrefaction Products Characterization}

The biochars were characterized using the methods described in Section 2.1. The $\mathrm{HHV}$ of the produced biochars was determined through the correlation established by Parikh et al. [42]:

$$
\mathrm{HHV}\left(\mathrm{MJ} \cdot \mathrm{kg}^{-1}, \mathrm{db}\right)=0.3536[\mathrm{FC}]+0.1559[\mathrm{VM}]-0.0078[\text { Ash }]
$$

where FC, VM, and Ash are the fixed carbon, volatile matter, and ash content of the biochar, respectively, expressed in wt.\%, db.

The aqueous phase of the torrefaction process was analyzed for $\mathrm{pH}$ (Crison MicropH 2001), conductivity (Mettler Toledo MC226 Conductivity Meter), chemical oxygen demand (COD) through the high range dichromate method (Hanna Instruments test kits), total phenolics content (TPC), and reducing sugars (RS). Total phenolics were quantified by the Folin-Ciocalteu method, as proposed by Singleton et al. [43], and total reducing sugars content was determined by the DNS method, as described by Miller [44]. All the analyses were performed in triplicate, and the presented results correspond to average values.

\subsection{Process Performance}

The mass and energy yields of the produced biochars were calculated using Equations (3) and (4), respectively:

$$
\begin{gathered}
\text { Mass yield }(\%)=\frac{m_{\text {biochar }}}{m_{\text {raw material }}} \times 100 \\
\text { Energy yield }(\%)=\left(\text { Mass yield } \times \frac{H H V_{\text {biochar }}}{H H V_{\text {raw material }}}\right) \times 100
\end{gathered}
$$

where $m_{\text {biochar }}$ and $H H V_{\text {biochar }}$ are the mass $(\mathrm{kg})$ and high heating value of biomass char $\left(\mathrm{MJ} \mathrm{Kg}{ }^{-1}\right.$ ) and $m_{\text {raw material }}$ and $H H V_{\text {raw material }}$ are the mass and high heating value of raw biomass material.

Process energy efficiency (PEE) compares the energy contained in the biochars with the sum of the energy in the original raw biomass plus the energy required for the torrefaction process. This parameter was calculated through Equation (5) [45]:

$$
\operatorname{PEE}(\%)=\frac{m_{\text {biochar }} \times H H V_{\text {biochar }}}{m_{\text {raw material }} \times H H V_{\text {raw material }}+Q_{\text {input }}} \times 100
$$

where $Q_{\text {input }}$ is the total energy requirements of the torrefaction process, in MJ. $Q_{\text {input }}$ was determined as the sum of the different energy requirements of the process, as follows:

$$
\begin{array}{r}
Q_{\text {input }}=Q_{1}+Q_{2}+Q_{3}+Q_{4}+Q_{5} \\
Q_{1}=m_{\text {raw material }} \times C p_{\text {raw material }} \times \Delta T \\
Q_{2}=m_{\mathrm{H}_{2} \mathrm{O}} \times C p_{\mathrm{H}_{2} \mathrm{O}} \times \Delta T \\
Q_{3}=m_{\mathrm{H}_{2} \mathrm{O}} \times L
\end{array}
$$


where $Q_{1}$ represents the energy needed to heat the feedstock from room temperature to process temperature $(\Delta \mathrm{T})$. The specific heat of the biomass sample ( $C p$ raw material) was evaluated using the values of $4.1 \times 10^{-3} \mathrm{MJ} \mathrm{Kg}^{-1} \mathrm{~K}^{-1}$ for algal biomass and of $1.7 \times 10^{-3}$ MJ Kg ${ }^{-1} \mathrm{~K}^{-1}$ for lignocellulosic material, used by Artan et al. [46], and taking into account their relative concentrations in the initial feedstock.

$Q_{2}$ represents the energy needed for heating the water present in the reactor $\left(m_{\mathrm{H} 2 \mathrm{O}}\right)$ from room temperature to $100{ }^{\circ} \mathrm{C}(\Delta \mathrm{T})$, considering the specific heat of water as $C p_{\mathrm{H} 2 \mathrm{O}}=$ $4.1379 \times 10^{-3} \mathrm{MJ} \mathrm{Kg}^{-1} \mathrm{~K}^{-1}$.

$Q_{3}$ is the latent heat of water vaporization $\left(\mathrm{L}=2.26 \mathrm{MJ} \mathrm{Kg}^{-1}\right)$, corresponding to the energy needed for water evaporation at $100{ }^{\circ} \mathrm{C}$.

$Q_{4}$ corresponds to the heat of reaction for the torrefaction process itself. This parameter was inferred from the values obtained by Ohliger et al. [47], for different temperatures, residence times, and moisture.

$Q_{5}$ are the thermal losses connected to the diffusion losses through the reactor walls and heat loss from the biochar and produced gas exiting the reactor. These thermal losses were assumed to be $45 \%$ at $300{ }^{\circ} \mathrm{C}$ and $60 \mathrm{~min}$ and $25 \%$ at $200{ }^{\circ} \mathrm{C}$ and $15 \mathrm{~min}$; the other values for all the combinations of temperature and residence time were interpolated [45].

\subsection{Response Surface Methodology}

For the study, four independent variables (temperature, residence time, incorporation rate of lignocellulosic material, and moisture content of algal biomass) were considered, using four or five levels for each variable (Table 1). Selection of the experimental conditions was based on the RSM model and Design-Expert ${ }^{\circledR}$ Software version 12-Stat-Ease (12.0.0.6), yielding a total of 39 experimental runs including 29 trials for model determination, 5 trials for lack of fit, and 5 replicates for pure error estimation as described in Table S1 (Supplementary Materials). The operational variables of the process were optimized considering the results obtained.

The $p$-value confidence level used to assess the model terms was $95 \%$. To verify the adequacy of the model, the value of the determination coefficient $\left(R^{2}\right)$ was compared to the adjusted value of $R^{2}$. The three-dimensional surface graphics generated by the software served to evaluate the interaction between the process variables and their effect on the output response.

Table 1. The independent variables and their experimental range and units. Lc-lignocellulosic material.

\begin{tabular}{lcccccc}
\hline \multicolumn{1}{c}{ Independent Variables } & Unit & \multicolumn{5}{c}{ Variable Range } \\
\hline Temperature & ${ }^{\circ} \mathrm{C}$ & 200 & 225 & 250 & 275 & 300 \\
Residence time & $\min$ & 15 & 30 & 45 & 60 & \\
Moisture content & $\%$ & 5 & 15 & 30 & 45 & 70 \\
Incorporation rate of Lc & $\%$ & 0 & 25 & 50 & 75 & 100 \\
\hline
\end{tabular}

\subsection{Adsorption Experiments}

Methylene blue (MB), a synthetic dye often present in industrial wastewaters, was used as a model compound to evaluate the biochar adsorption capacity towards cationic contaminants. The adsorption of MB by the produced biochars was measured with a quick adsorption method based on the work of Correia et al. [48]. The biomass or biochar samples were milled and sieved to less than $500 \mu \mathrm{m}$ diameter before use in the adsorption experiments. A small mass of each sample $(25 \mathrm{mg})$ was added to a test tube containing $5 \mathrm{~mL}$ of a MB aqueous solution (100 $\mathrm{mg} \mathrm{L}^{-1}$ ) and the tube was shaken for $3 \mathrm{~s}$ (Heidolph top shaker) and then centrifuged at $3000 \mathrm{rpm}$ for $5 \mathrm{~min}$ (Hettich EBA 20). The supernatant was transferred to another tube and the concentration of dye was determined by UV- 
VIS spectrophotometry (Biochrom Libra S4) at $664 \mathrm{~nm}$. The adsorption capacity (q) was determined using Equation (7):

$$
\mathrm{q}(\%)=\left(\frac{C_{i}-C_{f}}{C_{i}}\right) \times 100
$$

where $C_{i}$ and $C_{f}$ are the initial and final concentrations $\left(\mathrm{mg} \mathrm{L}^{-1}\right)$ of dye in the aqueous solution.

\section{Results and Discussion}

\subsection{Biomass Feedstock Characterization}

The characterization of the original feedstocks and the mixtures of microalgae and lignocellulosic biomass used in the torrefaction tests are presented in Table 2.

Table 2. Proximate analysis, ultimate analysis, and heating value of raw materials and mixtures used in the torrefaction tests ( $\mathrm{Cv}$-Chlorella vulgaris, Lc-lignocellulosic material).

\begin{tabular}{|c|c|c|c|c|c|}
\hline Biomass & $\mathrm{Cv}$ & Lc & $\begin{array}{c}75 \% \mathrm{Cv}+25 \% \\
\text { Lc }\end{array}$ & $\begin{array}{c}50 \% \mathrm{Cv}+50 \% \\
\text { Lc }\end{array}$ & $\begin{array}{c}25 \% \mathrm{Cv}+75 \% \\
\text { Lc }\end{array}$ \\
\hline \multicolumn{6}{|l|}{$\begin{array}{l}\text { Proximate analysis } \\
(w t . \%, d b)\end{array}$} \\
\hline Volatile matter & $86.46 \pm 0.74$ & $78.41 \pm 3.89$ & $84.45 \pm 0.85$ & $82.44 \pm 0.56$ & $80.43 \pm 1.89$ \\
\hline Fixed carbon & $6.01 \pm 0.73$ & $19.06 \pm 3.97$ & $9.27 \pm 1.03$ & $12.53 \pm 0.45$ & $15.79 \pm 0.54$ \\
\hline Moisture * & $6.35 \pm 0.52$ & $9.28 \pm 0.84$ & $7.08 \pm 0.68$ & $7.81 \pm 0.54$ & $8.54 \pm 0.67$ \\
\hline Ash & $7.53 \pm 0.09$ & $2.53 \pm 0.08$ & $6.28 \pm 0.02$ & $5.03 \pm 0.04$ & $3.78 \pm 0.07$ \\
\hline \multicolumn{6}{|l|}{$\begin{array}{l}\text { Ultimate analysis } \\
\text { (wt.\%, daf) }\end{array}$} \\
\hline $\mathrm{C}$ & $51.29 \pm 0.09$ & $50.10 \pm 0.16$ & $50.99 \pm 0.04$ & $50.70 \pm 0.12$ & $50.40 \pm 0.10$ \\
\hline $\mathrm{H}$ & $7.31 \pm 0.42$ & $6.21 \pm 0.09$ & $7.04 \pm 0.14$ & $6.76 \pm 0.24$ & $6.49 \pm 0.08$ \\
\hline $\mathrm{N}$ & $9.05 \pm 0.00$ & $1.10 \pm 0.08$ & $7.06 \pm 0.08$ & $5.08 \pm 0.02$ & $3.09 \pm 0.07$ \\
\hline$S$ & $0.24 \pm 0.04$ & $0.00 \pm 0.00$ & $0.18 \pm 0.00$ & $0.12 \pm 0.02$ & $0.06 \pm 0.01$ \\
\hline $\mathrm{O}$ & $32.11 \pm 0.10$ & $42.59 \pm 0.04$ & $34.73 \pm 0.02$ & $37.35 \pm 0.01$ & $39.97 \pm 0.04$ \\
\hline $\mathrm{O} / \mathrm{C}$ ratio & 0.47 & 0.64 & 0.51 & 0.55 & 0.60 \\
\hline $\mathrm{H} / \mathrm{C}$ ratio & 1.71 & 1.49 & 1.65 & 1.60 & 1.54 \\
\hline $\mathrm{HHV}\left(\mathrm{MJ} \mathrm{Kg} \mathrm{g}^{-1}\right) * *$ & 15.54 & 18.94 & 16.39 & 17.24 & 18.09 \\
\hline
\end{tabular}

${ }^{*}$ As received. ${ }^{* *}$ Dry basis.

Samples $\mathrm{Cv}$ and Lc presented significant differences in their proximate and ultimate compositions: $\mathrm{Cv}$ presented higher ash, nitrogen, and volatile matter contents while Lc showed higher concentrations of fixed carbon and oxygen. The lower ash content of Lc may be related to a higher $\mathrm{HHV}$, and its lower nitrogen content reduces the potential for harmful NOx emissions in case of energy recovery. Han et al. [49] determined the elemental analysis of the $C$. vulgaris biomass, obtaining values (C: $47.4 \% ; \mathrm{O}: 27.9 \% ; \mathrm{N}: 10.9 \% ; \mathrm{H}: 9.9 \%$; and S: $0.7 \%$ ) in line with those obtained in the present study, and confirming the tendency of high nitrogen concentrations in algal biomass.

The advantage of mixing lignocellulosic biomass with algal biomass is primarily to decrease the ash and nitrogen contents of algal biomass, improving its fuel quality. Furthermore, in real conditions, algal biomass can be obtained in the form of a decanted sludge, with high moisture content and the mixing with dried biomass residues can facilitate the process of sludge drying, even at atmospheric conditions. Microalgae coming from effluent treatments are not typically used in food or cosmetic applications and therefore do not undergo the same treatments as commercial microalgae (spray drying). Therefore, in this work, different mixtures of $\mathrm{Cv}$ and Lc biomasses were considered as a substrate for co-carbonization, and the moisture of the biomass mixtures was adjusted to controlled values by the addition of selected volumes of water. The purpose of this approach was to simulate the mixing of dried lignocellulosic biomass and decanted microalgae sludge and the direct use of the mixture as feed for biochar production. As seen in Table 2, additions of Lc of $25 \%, 50 \%$, and $75 \%$ of the feed were considered, and this approach had a significant effect on the ash content and nitrogen content of the feed, reaching values of $3.78 \%$ for ash content and 3.09\% for nitrogen content for the mixture with 75\% Lc. 


\subsection{Characterization of Torrefaction Products}

The conditions of the co-torrefaction experiments were selected according to a response surface methodology, in order to evaluate the influence of the following parameters: carbonization temperature, residence time, incorporation of lignocellulosic biomass in the feed, and moisture of the feed. A total of 39 experiments were performed and the solid and liquid products obtained were characterized for composition and relevant properties.

\subsubsection{Biochars}

The appearance of the biochars obtained by the torrefaction of microalgae and lignocellulosic biomass mixtures, with $50 \% \mathrm{Lc}$, at different temperatures and residence times is shown in Figure 1.

$300^{\circ} \mathrm{C}$

$60 \mathrm{~min}$

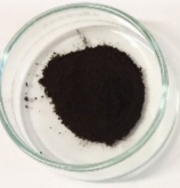

$250{ }^{\circ} \mathrm{C}$

$200{ }^{\circ} \mathrm{C}$
$45 \mathrm{~min}$.
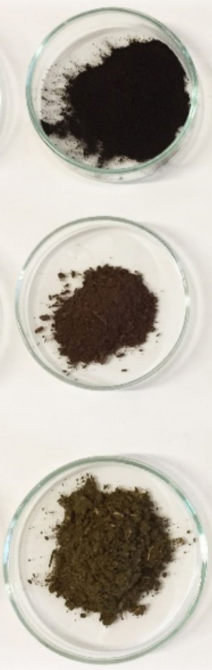

$30 \mathrm{~min}$.
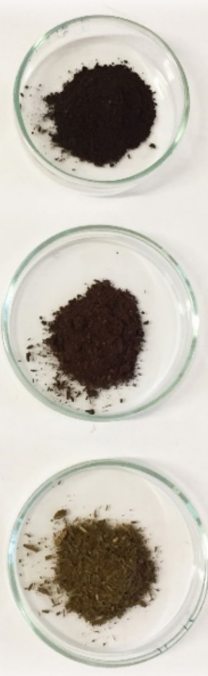

$15 \mathrm{~min}$
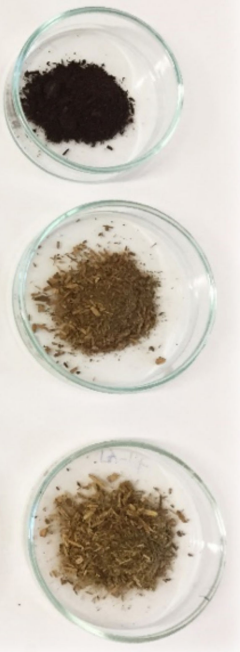

Figure 1. Biochars obtained for a feed mixture with $50 \% \mathrm{Lc}$ at different temperatures and residence times.

The variation in color intensity is clearly a function of the final torrefaction temperature. At the temperatures of $200{ }^{\circ} \mathrm{C}$, regardless of the residence time, there were no significant changes in the colors of biochars that were similar to the color of the feed mixture. This suggests that, at such mild conditions, the torrefaction process had minor effects on feedstock composition and structure, with changes restricted to the loss of water and volatile matter. Higher temperatures and longer residence times yielded darker biochars, indicating some degree of decomposition and rearrangement of the feedstock. The color of the biochars produced at $250{ }^{\circ} \mathrm{C}$ was influenced by the residence time while all biochars produced at $300{ }^{\circ} \mathrm{C}$ presented a homogeneous black color. As such, torrefaction temperature showed a larger impact on biochar color than torrefaction time, thus being responsible for a higher degree of decomposition and molecular rearrangement of the tested samples.

The proximate and ultimate compositions of the biochars were determined, as well as their HHV and MB adsorption capacity $\left(\mathrm{q}_{\mathrm{MB}}\right)$, to evaluate their suitability for energy or material applications (Table 3). 
Table 3. Proximate and elemental composition, HHV, and MB adsorption capacity of the 39 biochars.

\begin{tabular}{|c|c|c|c|c|c|c|c|c|c|c|c|c|c|c|}
\hline \multirow[t]{2}{*}{ Run } & \multirow{2}{*}{$\begin{array}{c}\mathrm{T} \\
\left({ }^{\circ} \mathrm{C}\right)\end{array}$} & \multirow{2}{*}{$\begin{array}{l}\text { Time } \\
(\mathrm{min})\end{array}$} & \multirow{2}{*}{$\begin{array}{l}M \\
(\%)\end{array}$} & \multirow{2}{*}{$\begin{array}{l}\text { Inc. } \\
(\%)\end{array}$} & \multicolumn{3}{|c|}{$\begin{array}{l}\text { Proximate Analysis } \\
(w \mathrm{t} . \%, \mathrm{db})\end{array}$} & \multicolumn{5}{|c|}{$\begin{array}{l}\text { Ultimate Analysis } \\
\text { (wt.\%, daf) }\end{array}$} & \multirow{2}{*}{$\begin{array}{c}\mathrm{HHV} \\
(\mathrm{MJ} \\
\left.\mathrm{Kg}^{-1} \mathrm{db}\right)\end{array}$} & \multirow[t]{2}{*}{$\begin{array}{c}\mathrm{qMB}_{\mathrm{M}} \\
\mathbf{( \% )}\end{array}$} \\
\hline & & & & & Ash & VM & FC & $\mathbf{N}$ & $C$ & $\mathbf{H}$ & $S$ & $\mathrm{O}$ & & \\
\hline 1 & 300 & 60 & 30 & 50 & 20.9 & 43.2 & 35.9 & 4.7 & 68.9 & 5.5 & 0.3 & 20.7 & 19.3 & 13.0 \\
\hline 2 & 300 & 60 & 15 & 25 & 15.0 & 56.0 & 29.0 & 9.4 & 69.8 & 6.2 & 0.4 & 14.2 & 18.9 & 20.5 \\
\hline 3 & 300 & 60 & 15 & 25 & 16.6 & 55.0 & 29.4 & 9.9 & 71.9 & 6.3 & 0.4 & 11.5 & 18.9 & 18.9 \\
\hline 4 & 300 & 45 & 45 & 0 & 12.6 & 64.6 & 22.9 & 12.3 & 68.1 & 6.7 & 0.7 & 12.3 & 18.0 & 17.0 \\
\hline 5 & 300 & 45 & 5 & 100 & 6.5 & 58.6 & 34.9 & 1.5 & 70.2 & 5.1 & 1.2 & 21.9 & 21.4 & 15.6 \\
\hline 6 & 300 & 45 & 5 & 50 & 16.8 & 53.5 & 29.8 & 7.9 & 71.0 & 6.1 & 0.4 & 14.6 & 18.7 & 17.9 \\
\hline 7 & 300 & 45 & 5 & 0 & 12.3 & 62.6 & 25.1 & 12.1 & 70.1 & 6.7 & 0.5 & 10.6 & 18.5 & 15.3 \\
\hline 8 & 300 & 30 & 30 & 50 & 10.5 & 63.0 & 26.6 & 5.0 & 61.2 & 6.0 & 0.2 & 27.6 & 19.1 & 18.3 \\
\hline 9 & 300 & 15 & 45 & 25 & 9.5 & 75.0 & 15.5 & 7.0 & 55.0 & 6.5 & 0.3 & 31.3 & 17.1 & 52.1 \\
\hline 10 & 300 & 15 & 45 & 0 & 9.0 & 77.0 & 13.9 & 11.2 & 59.6 & 7.0 & 0.5 & 21.8 & 16.9 & 58.9 \\
\hline 11 & 300 & 15 & 5 & 50 & 8.6 & 69.9 & 21.6 & 6.5 & 61.5 & 6.4 & 0.2 & 25.5 & 18.4 & 19.6 \\
\hline 12 & 275 & 60 & 70 & 0 & 11.1 & 68.6 & 20.3 & 12.6 & 66.6 & 6.9 & 0.5 & 13.4 & 17.8 & 18.1 \\
\hline 13 & 275 & 45 & 30 & 25 & 9.3 & 67.4 & 23.3 & 8.1 & 64.8 & 5.9 & 0.7 & 20.5 & 18.7 & 17.8 \\
\hline 14 & 250 & 60 & 15 & 0 & 9.6 & 75.3 & 15.5 & 12.0 & 61.9 & 7.0 & 0.4 & 18.7 & 17.2 & 38.8 \\
\hline 15 & 250 & 60 & 5 & 50 & 10.9 & 71.0 & 18.1 & 7.4 & 59.0 & 6.5 & 0.2 & 26.9 & 17.4 & 33.5 \\
\hline 16 & 250 & 45 & 30 & 50 & 19.2 & 66.5 & 14.3 & 4.8 & 56.8 & 5.6 & 0.0 & 32.8 & 15.3 & 34.2 \\
\hline 17 & 250 & 45 & 30 & 25 & 13.4 & 69.8 & 16.9 & 8.9 & 59.4 & 6.6 & 0.3 & 24.8 & 16.7 & 37.5 \\
\hline 18 & 250 & 45 & 30 & 25 & 12.6 & 71.7 & 15.7 & 9.5 & 58.7 & 6.6 & 0.3 & 25.0 & 16.6 & 37.4 \\
\hline 19 & 250 & 45 & 15 & 25 & 9.5 & 75.1 & 15.4 & 9.3 & 58.1 & 6.7 & 0.3 & 25.6 & 17.1 & 38.4 \\
\hline 20 & 250 & 45 & 15 & 25 & 9.7 & 76.2 & 14.1 & 8.6 & 57.7 & 6.5 & 0.6 & 26.7 & 16.8 & 39.0 \\
\hline 21 & 250 & 30 & 45 & 25 & 11.4 & 75.0 & 13.6 & 5.7 & 54.5 & 6.7 & 0.3 & 32.8 & 16.4 & 63.0 \\
\hline 22 & 250 & 30 & 45 & 25 & 11.3 & 76.6 & 12.1 & 4.9 & 53.4 & 6.8 & 0.2 & 34.8 & 16.1 & 62.1 \\
\hline 23 & 250 & 30 & 15 & 50 & 14.5 & 68.4 & 17.1 & 6.0 & 59.0 & 6.8 & 0.2 & 28.1 & 16.6 & 52.6 \\
\hline 24 & 250 & 30 & 5 & 25 & 7.5 & 75.9 & 16.6 & 7.6 & 55.5 & 6.2 & 0.7 & 30.1 & 17.6 & 69.9 \\
\hline 25 & 250 & 15 & 30 & 50 & 9.6 & 75.4 & 15.1 & 6.1 & 51.2 & 6.6 & 0.2 & 36.0 & 17.0 & 78.8 \\
\hline 26 & 250 & 15 & 5 & 0 & 8.0 & 79.3 & 12.7 & 9.8 & 54.6 & 7.1 & 0.3 & 28.2 & 16.8 & 87.9 \\
\hline 27 & 250 & 15 & 5 & 0 & 8.0 & 77.7 & 14.3 & 10.6 & 56.2 & 7.6 & 0.4 & 25.3 & 17.1 & 88.4 \\
\hline 28 & 225 & 60 & 5 & 25 & 7.4 & 78.0 & 14.6 & 8.8 & 56.4 & 7.3 & 0.3 & 27.1 & 17.3 & 88.8 \\
\hline 29 & 225 & 45 & 45 & 0 & 8.5 & 84.4 & 7.1 & 10.5 & 56.2 & 7.6 & 0.5 & 25.2 & 15.6 & 86.0 \\
\hline 30 & 225 & 15 & 15 & 25 & 10.5 & 87.4 & 2.2 & 8.7 & 52.0 & 7.4 & 0.5 & 31.6 & 14.3 & 94.4 \\
\hline 31 & 200 & 60 & 45 & 25 & 10.6 & 77.8 & 11.7 & 7.7 & 52.3 & 6.8 & 0.4 & 32.8 & 16.2 & 50.8 \\
\hline 32 & 200 & 60 & 30 & 50 & 15.6 & 71.4 & 13.0 & 4.2 & 55.0 & 6.8 & 0.0 & 34.0 & 15.6 & 80.7 \\
\hline 33 & 200 & 60 & 5 & 0 & 8.0 & 77.1 & 14.9 & 10.0 & 54.4 & 7.3 & 0.7 & 27.6 & 17.2 & 90.2 \\
\hline 34 & 200 & 30 & 15 & 25 & 10.0 & 75.8 & 15.3 & 8.0 & 51.2 & 7.2 & 0.5 & 33.2 & 17.1 & 91.5 \\
\hline 35 & 200 & 30 & 15 & 25 & 11.0 & 75.0 & 14.0 & 8.4 & 51.6 & 7.1 & 0.6 & 32.3 & 16.6 & 95.4 \\
\hline 36 & 200 & 30 & 5 & 50 & 7.6 & 75.3 & 17.1 & 7.6 & 50.8 & 6.8 & 0.3 & 34.5 & 17.7 & 91.3 \\
\hline 37 & 200 & 15 & 70 & 0 & 8.9 & 87.7 & 3.4 & 9.8 & 51.2 & 7.1 & 0.3 & 31.6 & 14.8 & 60.4 \\
\hline 38 & 200 & 15 & 30 & 50 & 8.4 & 78.2 & 13.4 & 5.1 & 47.3 & 6.7 & 0.0 & 40.9 & 16.9 & 75.4 \\
\hline 39 & 200 & 15 & 30 & 25 & 8.1 & 77.9 & 14.0 & 5.0 & 47.1 & 6.7 & 0.0 & 41.2 & 17.0 & 91.1 \\
\hline
\end{tabular}

Note: $\mathrm{T}$-temperature; $\mathrm{M}-$ moisture; Inc.- incorporation of lignocellulosic material; $\mathrm{q}_{\mathrm{MB}}-\mathrm{MB}$ adsorption capacity.

Biochars obtained at higher temperatures and residence times presented a higher amount of fixed carbon and less volatile matter. The incorporation of lignocellulosic biomass decreased the ash content of the biochars (12.6 to $4.8 \%$ ) because of the higher ash content of the $\mathrm{Cv}$ sample. The HHVs of the biochars presented the lowest and highest values of 14.8 and $21.4 \mathrm{MJ} \mathrm{Kg}^{-1}$, for $0 \% \mathrm{Lc}$ and $100 \% \mathrm{Lc}$, respectively. This parameter was significantly improved for samples subjected to more severe torrefaction conditions and decreased for a greater amount of water in the feedstock. In particular, HHVs higher than $18 \mathrm{MJ} \mathrm{Kg}^{-1}$ were obtained for mixtures with the incorporation of Lc from $0 \%$ to $50 \%$ at the temperatures of $275^{\circ} \mathrm{C}$ and $300^{\circ} \mathrm{C}$. Similar conclusions were drawn by Chen et al. [22] for biochars produced from sawdust, wheat straw, pine, and microalgae. In general, the biochars with better fuel properties were those subjected to a torrefaction process at temperatures above $275{ }^{\circ} \mathrm{C}$ and residence time above $45 \mathrm{~min}$, which shows that nitro- 
gen elimination and deoxygenation reactions played a major effect on the biochar final properties [50].

The variation of the elemental composition of the biochars relative to the feedstocks, expressed as their $\mathrm{H} / \mathrm{C}$ and $\mathrm{O} / \mathrm{C}$ atomic ratios, is shown in a van Krevelen diagram (Figure 2).

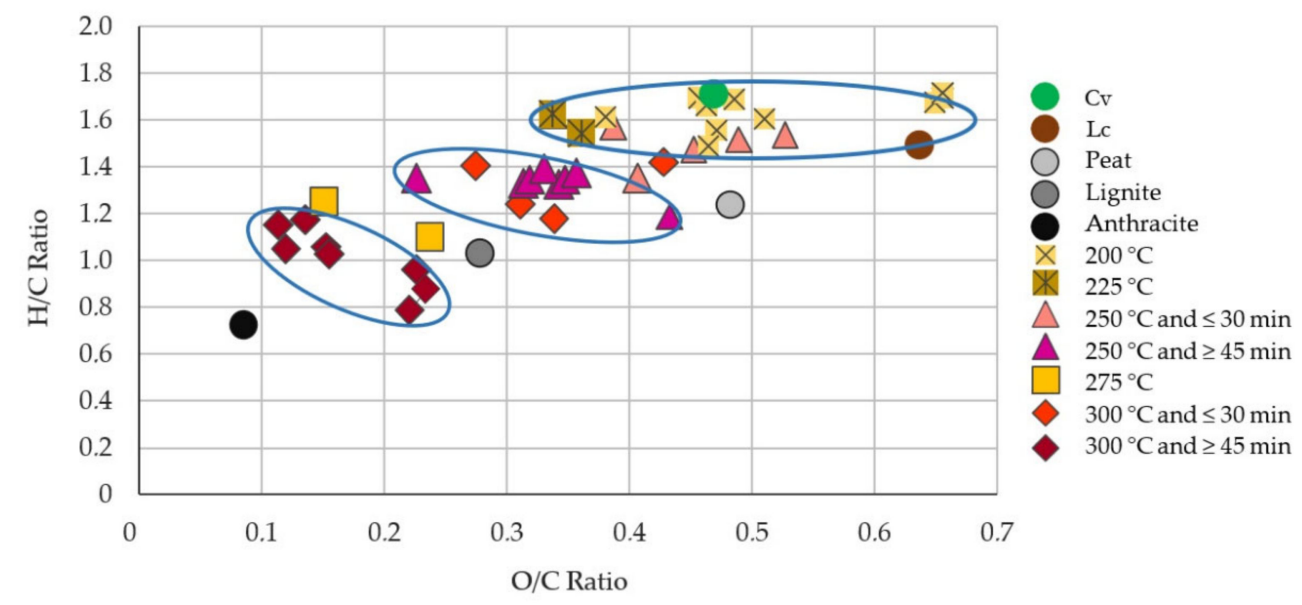

Figure 2. Van Krevelen diagram for samples Cv (algal biomass), Lc (lenhocelulosic material), and the obtained biochars for different fossil fuels [51].

As can be seen, the biochars produced at $200{ }^{\circ} \mathrm{C}$ and $225^{\circ} \mathrm{C}$ evidenced some degree of deoxygenation, expressed as a decrease of the $\mathrm{O} / \mathrm{C}$ ratio relative to the raw materials $\mathrm{Cv}$ and $\mathrm{Lc}$, but no significant structural rearrangements were detected since the $\mathrm{H} / \mathrm{C}$ ratio was comparable to the feedstocks. As the torrefaction temperature increases the deoxygenation reactions become more relevant leading to biochars with $\mathrm{O} / \mathrm{C}$ ratios between those of lignite and anthracite, demonstrating the upgrading effect on fuel quality [52]. For torrefaction temperatures higher than $250^{\circ} \mathrm{C}$, a temperature-dependent decrease of the $\mathrm{H} / \mathrm{C}$ ratio also occurred, indicating that the rearrangement of the carbonaceous structure takes place with increasing formation of aromatic structures [53].

In contrast, the adsorption capacity for methylene blue ( $\mathrm{q}_{\mathrm{MB}}$ ) was negatively influenced by the torrefaction capacity, since $\mathrm{q}_{\mathrm{MB}}$ values higher than $60 \%$ were obtained for biochars produced at $250{ }^{\circ} \mathrm{C}$ or lower (Table 3 ). Since methylene blue is a cationic dye, this behavior agrees with the adsorption of the dye due to ion exchange, hydrogen bonding, and electrostatic interactions with the carboxyl groups from the feedstock, which are partially retained in the biochar surface if the carbonaceous structure is not strongly modified, that is, for the lower torrefaction temperatures [48]. Severe torrefaction conditions lead to more significant rearrangement in the lignocellulosic structure of biochars with Lc, altering the surface porosity, by removing the binding- $\mathrm{OH}$ groups $[54,55]$. The biochars with the highest adsorption capacity were obtained at $200{ }^{\circ} \mathrm{C}, 30 \mathrm{~min}$, and $25 \%$ of lignocellulosic material incorporation and 15\% moisture, reaching 95\% adsorption. Some biochars showed a better adsorption efficiency than the original biomasses' feedstocks $(59.2 \%$ for $\mathrm{Cv}$ and $18.3 \%$ for Lc), which may be the result of an increase of hydroxyl and carboxyl groups generated on the biochar surface by hydrolysis reactions at low torrefaction temperatures. Relative to the raw biomasses, biochars also have the advantage of being less susceptible to chemical or microbial degradation, because of their lower moisture content [56].

The $\mathrm{q}_{\mathrm{MB}}$ of the biochars was not influenced by the percentage of Lc incorporation, probably because both feedstocks present anionic groups in their surface that may be involved in the adsorption process $[57,58]$.

The adsorption capacity of a commercial activated carbon is close to $100 \%$ for several contaminants, including $\mathrm{MB}$, because it involves porous adsorption, a more effective and extensive adsorption mode. Nevertheless, activated carbon production is expensive, 
energy-demanding, and generates contaminated effluents; thus, its use should be reserved for specific high-value applications, while low-cost biochars may be used for the preliminary treatment of highly contaminated effluents produced in high volumes [59]. Thus, by choosing the operational conditions it is possible to obtain biochars with characteristics more adequate for use as an alternative adsorbent for cationic species or to incorporate in solid fuels. The incorporation of Lc biomass is more relevant for the energy application, allowing the moisture of the feedstock mixture to be reduced and the composition of the biochar product to be improved.

\subsubsection{Aqueous Phase}

The torrefaction process yields a liquid by-product mainly composed of water recovered from the feedstock moisture and dehydration reaction. This aqueous phase contains various organic products produced during the decomposition of the feedstock and distilled at the reaction temperature. Those volatile organic products are either dissolved in the aqueous phase (if they have moderate to high dipole moment) or in the form of suspended droplets or particles (if they are non-polar compounds with low solubility in water). In some of the torrefaction conditions, the concentration of non-polar organic products was high enough to form a water immiscible organic phase (bio-oil) that separated from the aqueous phase upon cooling of the condensated liquid products. This bio-oil product was separated by decantation before the characterization of the aqueous phase. The presence of dissolved or suspended organic compounds confers specific properties to the aqueous phase, namely, influences its $\mathrm{pH}$ conductivity, total phenolic components, total sugars, and chemical oxygen demand. Characterization of the aqueous phases from all torrefaction tests was performed to evaluate the influence of operational parameters in these properties and is presented in Table 4.

Table 4. Characterization of the aqueous phase of the 39 torrefaction tests.

\begin{tabular}{|c|c|c|c|c|c|c|c|c|c|}
\hline Run & $\begin{array}{c}\mathrm{T} \\
\left({ }^{\circ} \mathrm{C}\right)\end{array}$ & $\begin{array}{l}\text { Time } \\
\text { (min) }\end{array}$ & $\begin{array}{c}M \\
(\%)\end{array}$ & $\begin{array}{l}\text { Inc. } \\
(\%)\end{array}$ & $\mathrm{pH}$ & $\begin{array}{c}\text { Conductivity } \\
\mathrm{mS} \mathrm{cm}^{-1}\end{array}$ & $\begin{array}{c}\text { TPC } \\
\left(\mathrm{mg} \mathrm{L}^{-1}\right)\end{array}$ & $\begin{array}{c}\text { COD } \\
\left(\mathrm{g} \mathrm{O}_{2} \mathrm{~L}^{-1}\right)\end{array}$ & $\begin{array}{c}\mathrm{RS} \\
\left(\mathrm{mg} \mathrm{L^{-1 }}\right)\end{array}$ \\
\hline 1 & 300 & 60 & 30 & 50 & 4.0 & 1.1 & 7940 & 39.6 & 14,500 \\
\hline 2 & 300 & 60 & 15 & 25 & 6.8 & 19.9 & 5215 & 41.3 & 4500 \\
\hline 3 & 300 & 60 & 15 & 25 & 8.0 & 19.9 & 5758 & 39.8 & 2500 \\
\hline 4 & 300 & 45 & 45 & 0 & 9.0 & 34.6 & 3075 & 40.0 & 2750 \\
\hline 5 & 300 & 45 & 5 & 100 & 4.2 & 3.8 & 40,547 & 766.0 & 54,000 \\
\hline 6 & 300 & 45 & 5 & 50 & 5.0 & 37.6 & 9631 & 68.4 & 6000 \\
\hline 7 & 300 & 45 & 5 & 0 & 9.0 & 24.1 & 7108 & 67.0 & 3750 \\
\hline 8 & 300 & 30 & 30 & 50 & 4.0 & 19.6 & 6586 & 40.0 & 5750 \\
\hline 9 & 300 & 15 & 45 & 25 & 6.0 & 10.0 & 1256 & 23.6 & 2500 \\
\hline 10 & 300 & 15 & 45 & 0 & 6.5 & 19.2 & 1104 & 40.0 & 1250 \\
\hline 11 & 300 & 15 & 5 & 50 & 5.5 & 29.0 & 6318 & 43.0 & 2500 \\
\hline 12 & 275 & 60 & 70 & 0 & 8.5 & 16.7 & 861 & 24.6 & 750 \\
\hline 13 & 275 & 45 & 30 & 25 & 6.8 & 11.2 & 7944 & 40.1 & n.d. \\
\hline 14 & 250 & 60 & 15 & 0 & 7.3 & 40.0 & 3223 & 40.4 & 750 \\
\hline 15 & 250 & 60 & 5 & 50 & 5.0 & 13.3 & 7141 & 42.1 & 3000 \\
\hline 16 & 250 & 45 & 30 & 50 & 4.5 & 10.2 & 2191 & 38.5 & 1000 \\
\hline 17 & 250 & 45 & 30 & 25 & 6.0 & 19.5 & 2133 & 41.3 & 2500 \\
\hline 18 & 250 & 45 & 30 & 25 & 5.5 & 19.2 & 2059 & 39.6 & 2200 \\
\hline 19 & 250 & 45 & 15 & 25 & 5.8 & 19.1 & 4763 & 40.1 & 4000 \\
\hline 20 & 250 & 45 & 15 & 25 & 6.2 & 18.2 & 2543 & 39.8 & 3000 \\
\hline 21 & 250 & 30 & 45 & 25 & 6.8 & 19.9 & 411 & 15.5 & n.d. \\
\hline 22 & 250 & 30 & 45 & 25 & 6.2 & 8.6 & 340 & 14.3 & n.d. \\
\hline 23 & 250 & 30 & 15 & 50 & 5.1 & 18.6 & 2414 & 39.8 & 3500 \\
\hline 24 & 250 & 30 & 5 & 25 & 6.1 & 11.2 & 7682 & 38.5 & n.d. \\
\hline 25 & 250 & 15 & 30 & 50 & 6.9 & 4.0 & 263 & 24.7 & n.d. \\
\hline 26 & 250 & 15 & 5 & 0 & 6.0 & 18.0 & 6887 & 40.5 & 2000 \\
\hline 27 & 250 & 15 & 5 & 0 & 6.0 & 18.5 & 6783 & 40.4 & 1980 \\
\hline 28 & 225 & 60 & 5 & 25 & 6.2 & 17.0 & 5653 & 39.6 & 1000 \\
\hline
\end{tabular}


Table 4. Cont

\begin{tabular}{|c|c|c|c|c|c|c|c|c|c|}
\hline Run & $\begin{array}{c}\mathrm{T} \\
\left({ }^{\circ} \mathrm{C}\right)\end{array}$ & $\begin{array}{l}\text { Time } \\
\text { (min) }\end{array}$ & $\begin{array}{c}M \\
(\%)\end{array}$ & $\begin{array}{l}\text { Inc. } \\
\text { (\%) }\end{array}$ & pH & $\begin{array}{l}\text { Conductivity } \\
\mathrm{mS} \mathrm{cm}^{-1}\end{array}$ & $\begin{array}{c}\text { TPC } \\
\left(\mathrm{mg} \mathrm{L}^{-1}\right)\end{array}$ & $\begin{array}{c}\text { COD } \\
\left(\mathrm{g} \mathrm{O}_{2} \mathrm{~L}^{-1}\right)\end{array}$ & $\begin{array}{c}\mathrm{RS} \\
\left(\mathrm{mg} \mathrm{L}^{-1}\right)\end{array}$ \\
\hline 29 & 225 & 45 & 45 & 0 & 6.1 & 9.8 & 549 & 28.8 & n.d. \\
\hline 30 & 225 & 15 & 15 & 25 & 6.5 & 8.5 & 225 & 21.8 & 500 \\
\hline 31 & 200 & 60 & 45 & 25 & 9.0 & 5.5 & 73 & 6.7 & 2500 \\
\hline 32 & 200 & 60 & 30 & 50 & 8.3 & 6.2 & 182 & 13.8 & 500 \\
\hline 33 & 200 & 60 & 5 & 0 & 7.1 & 5.5 & 1474 & 37.9 & n.d. \\
\hline 34 & 200 & 30 & 15 & 25 & 6.9 & 4.2 & 248 & 22.3 & n.d. \\
\hline 35 & 200 & 30 & 15 & 25 & 7.5 & 8.2 & 187 & 18.5 & n.d. \\
\hline 36 & 200 & 30 & 5 & 50 & 7.1 & 2.2 & 506 & 39.5 & n.d. \\
\hline 37 & 200 & 15 & 70 & 0 & 6.2 & 1.1 & 22 & 0.8 & n.d. \\
\hline 38 & 200 & 15 & 30 & 50 & 7.1 & 2.2 & 780 & 5.1 & 1000 \\
\hline 39 & 200 & 15 & 30 & 25 & 7.0 & 2.1 & 35 & 5.1 & 1100 \\
\hline
\end{tabular}

Note: T-temperature; M-moisture; Inc.—incorporation of lignocellulosic material; TPC—total phenolic compounds; COD—chemical oxygen demand; RS—reducing sugars; n.d.-not detected.

As expected, torrefaction trials with higher temperature and residence time led to aqueous phase samples with a greater load of organic components, resulting in higher $\operatorname{COD}\left(766 \mathrm{~g} \mathrm{O}_{2} \mathrm{~L}^{-1}\right)$, reducing sugars $\left(54,000 \mathrm{mg} \mathrm{L}^{-1}\right)$, and total phenolics $\left(40,547 \mathrm{mg} \mathrm{L}^{-1}\right)$. The increase in phenolic compounds concentration is largely due to the degradation of lignin and hemicellulose that occurs to a greater extent at higher temperatures, such as 275 and $300{ }^{\circ} \mathrm{C}$ [60]. Moreover, at temperatures of $250{ }^{\circ} \mathrm{C}$ and higher, cellulose suffers decomposition reactions leading to the formation of acids and alcohols and aldehydes and ketones such as acetic acid, oxalic acid, acetone, acetaldehyde, and propanoic acid [38].

The increase in moisture led to a significant decrease in the total phenolic content (from 40,547 to $22 \mathrm{mg} \mathrm{L}^{-1}$ ), COD (from $766 \mathrm{~g} \mathrm{~L}^{-1}$ to 0.8 ), and reducing sugars (from $54,000 \mathrm{mg}$ $\mathrm{L}^{-1}$ to n.d.), potentially related to a dilution effect [38]. On the other hand, decreasing the incorporation of lignocellulosic material resulted in a reduction in total phenolics and reducing sugars, but a slight increase in COD, which may be related to the fact that microalgae may yield lower amounts of reducing sugars and phenolic compounds than lignocellulosic biomass, but their decomposition generates other organic analytes, such as simple sugars, organic acids, and amino acids, that contribute to the COD value [38].

Conductivity and $\mathrm{pH}$ were also higher in the situations of greater reaction severity, because of the dissolution of polar and acidic organic products. According to Cahyanti et al. [61], biomass torrefaction condensates produced below $300{ }^{\circ} \mathrm{C}$ are potential inhibitors of microbiological processes due to their concentrations in phenolic compounds, furans, and polycyclic aromatic hydrocarbons (PAHs), whose concentration increases with the severity of the torrefaction process [61]. For this reason, the use of the aqueous phases of the torrefaction process has been studied in agriculture as an herbicide and pest repellent [61]. This product is also known as pyroligneous acid, and it is known for its effect as an antimicrobial agent, insecticide, antioxidant, and for having properties to promote seed germination and plant growth. It mostly consists of aromatic, aliphatic, and naphthenic hydrocarbons and other oxygenated compounds such as aldehydes, alcohols, furans, ketones, acids, phenols, and ethers [62].

\subsection{Torrefaction Process Performance}

The torrefaction process converted the feedstocks to solid, liquid, and gas products at yields that were determined gravimetrically and are shown in Table 5 . The condensates included two immiscible phases (aqueous phase and bio-oils) that were separated by decantation for individual accounting and characterization. 
Table 5. Product yields (biochar, condensates, and gas) from the 39 torrefaction tests.

\begin{tabular}{|c|c|c|c|c|c|c|c|c|}
\hline \multirow[b]{2}{*}{ Run } & \multirow[b]{2}{*}{$\begin{array}{c}\mathrm{T} \\
\left({ }^{\circ} \mathrm{C}\right)\end{array}$} & \multirow[b]{2}{*}{$\begin{array}{l}\text { Time } \\
\text { (min) }\end{array}$} & \multirow[b]{2}{*}{$\begin{array}{l}\text { Moisture } \\
\text { (\%) }\end{array}$} & \multirow[b]{2}{*}{$\begin{array}{c}\text { Incorporation } \\
(\%)\end{array}$} & \multirow[b]{2}{*}{$\begin{array}{l}\text { Biochar } \\
(\%)\end{array}$} & \multicolumn{2}{|c|}{ Condensate } & \multirow[b]{2}{*}{$\begin{array}{l}\text { Gas } \\
(\%)\end{array}$} \\
\hline & & & & & & $\begin{array}{c}\text { Aqueous } \\
\text { Phase } \\
(\%)\end{array}$ & $\begin{array}{c}\text { Bio-Oil } \\
(\%)\end{array}$ & \\
\hline 1 & 300 & 60 & 30 & 50 & 36.5 & 46.0 & 6.0 & 11.5 \\
\hline 2 & 300 & 60 & 15 & 25 & 46.0 & 33.5 & 11.5 & 9.0 \\
\hline 3 & 300 & 60 & 15 & 25 & 46.0 & 34.0 & 10.0 & 10.0 \\
\hline 4 & 300 & 45 & 45 & 0 & 31.0 & 47.0 & 8.0 & 14.0 \\
\hline 5 & 300 & 45 & 5 & 100 & 52.5 & 0.7 & 35.8 & 11.0 \\
\hline 6 & 300 & 45 & 5 & 50 & 55.0 & 23.5 & 13.0 & 8.5 \\
\hline 7 & 300 & 45 & 5 & 0 & 58.0 & 16.0 & 19.0 & 7.0 \\
\hline 8 & 300 & 30 & 30 & 50 & 51.0 & 39.0 & 5.0 & 5.0 \\
\hline 9 & 300 & 15 & 45 & 25 & 42.0 & 51.5 & 2.0 & 4.5 \\
\hline 10 & 300 & 15 & 45 & 0 & 41.5 & 44.0 & 10.0 & 4.5 \\
\hline 11 & 300 & 15 & 5 & 50 & 70.0 & 10.0 & 2.5 & 17.5 \\
\hline 12 & 275 & 60 & 70 & 0 & 23.0 & 57.5 & 1.0 & 18.5 \\
\hline 13 & 275 & 45 & 30 & 25 & 40.5 & 45.5 & 8.0 & 6.0 \\
\hline 14 & 250 & 60 & 15 & 0 & 59.5 & 29.5 & 10.0 & 1.0 \\
\hline 15 & 250 & 60 & 5 & 50 & 76.5 & 13.5 & 3.0 & 7.0 \\
\hline 16 & 250 & 45 & 30 & 50 & 53.5 & 30.0 & 1.5 & 15.0 \\
\hline 17 & 250 & 45 & 30 & 25 & 52.0 & 39.2 & 4.8 & 4.0 \\
\hline 18 & 250 & 45 & 30 & 25 & 51.0 & 38.1 & 4.9 & 6.0 \\
\hline 19 & 250 & 45 & 15 & 25 & 66.5 & 18.0 & 2.0 & 13.5 \\
\hline 20 & 250 & 45 & 15 & 25 & 66.5 & 18.0 & 2.5 & 13.0 \\
\hline 21 & 250 & 30 & 45 & 25 & 45.0 & 50.0 & 2.5 & 2.5 \\
\hline 22 & 250 & 30 & 45 & 25 & 46.0 & 49.0 & 3.0 & 2.0 \\
\hline 23 & 250 & 30 & 15 & 50 & 73.5 & 20.0 & 0.5 & 6.0 \\
\hline 24 & 250 & 30 & 5 & 25 & 80.5 & 14.9 & 1.1 & 3.5 \\
\hline 25 & 250 & 15 & 30 & 50 & 70.0 & 18.0 & 0.0 & 12.0 \\
\hline 26 & 250 & 15 & 5 & 0 & 85.5 & 5.0 & 0.0 & 9.5 \\
\hline 27 & 250 & 15 & 5 & 0 & 86.0 & 6.0 & 0.0 & 8.0 \\
\hline 28 & 225 & 60 & 5 & 25 & 85.0 & 9.5 & 2.0 & 3.5 \\
\hline 29 & 225 & 45 & 45 & 0 & 47.5 & 33.5 & 0.0 & 19.0 \\
\hline 30 & 225 & 15 & 15 & 25 & 78.5 & 20.5 & 0.0 & 1.0 \\
\hline 31 & 200 & 60 & 45 & 25 & 47.0 & 28.5 & 0.0 & 24.5 \\
\hline 32 & 200 & 60 & 30 & 50 & 70.5 & 24.0 & 0.0 & 5.5 \\
\hline 33 & 200 & 60 & 5 & 0 & 90.0 & 9.0 & 0.0 & 1.0 \\
\hline 34 & 200 & 30 & 15 & 25 & 79.5 & 15.5 & 0.0 & 5.0 \\
\hline 35 & 200 & 30 & 15 & 25 & 78.0 & 14.5 & 0.0 & 7.5 \\
\hline 36 & 200 & 30 & 5 & 50 & 90.5 & 4.5 & 0.0 & 5.0 \\
\hline 37 & 200 & 15 & 70 & 0 & 61.0 & 32.0 & 0.0 & 7.0 \\
\hline 38 & 200 & 15 & 30 & 50 & 69.5 & 25.0 & 0.0 & 5.5 \\
\hline 39 & 200 & 15 & 30 & 25 & 69.5 & 25.0 & 0.0 & 5.5 \\
\hline
\end{tabular}

Biochar yield decreased from 90.5 to $23.0 \%$ with increasing temperature or residence time due to a higher thermal decomposition of the raw materials, leading to an increase of the aqueous phase yields ( 0.7 to $57.5 \%$ ), bio-oil (0 to $35.8 \%$ ), and gas products (1.0 to $24.5 \%$ ).

As expected, biochar yields also decreased with increasing water content of the feed due to lower availability of carbonaceous components [31]. Initial feed moisture had a positive correlation with the yields of the aqueous phase and gas products because it contributes to a net water volume and may increase the extension of some hydrothermal oxidation reactions [63]. Generally, high biochar yields indicate that most of the feedstock carbon was recovered in the solid products, while high yields of condensates and gases may be related to their availability in the feed but also a higher degree of decomposition reactions. The loss of feedstock mass as volatile components was positively correlated with a decrease in the $\mathrm{O} / \mathrm{C}$ and $\mathrm{H} / \mathrm{C}$ ratios of the biochars, confirming an upgrading effect by the thermochemical process of torrefaction. 
Bio-oil yield showed a linear correlation with operating temperature because of the increase in the formation of organic by-products through pyrolytic processes involving covalent bond breaking and deoxygenation processes [62]. The influence of residence time in the bio-oil yield was more evident for tests performed at more than $30 \mathrm{~min}$, probably due to kinetic limitations of the thermal degradation processes [64]. At comparable temperatures, bio-oil yields were lower for higher moisture contents $(>5 \%)$, which may be related to the increase of aqueous phase volume and consequent dissolution of higher amounts of bio-oil components such as aromatic hydrocarbons (e.g., naphthalene) and carboxylic acids (e.g., acetic acid) [65].

The incorporation of lignocellulosic material did not show a clear correlation with product yields because both feedstocks are susceptible to thermal degradation in the range of operating conditions used.

Biochar yields higher than $80 \%$ were obtained for the tests performed with $5 \%$ of moisture at 200 to $250{ }^{\circ} \mathrm{C}$ and with the incorporation of at least $50 \%$ lignocellulosic material.

It is known that torrefaction increases the hydrophobicity of the torrefied material, as well as its energy density, whilst reducing biomass tenacity [61]. Torrefaction makes the product more energy-dense due to the elimination of oxygen in the pyrolytic degradation reactions. Zhang et al. [66] studied the torrefaction of microalgae and assigned decarbonization, dehydrogenation, and deoxygenation levels of 20,60 , and $93 \%$, respectively, for the biochar product obtained at $300^{\circ} \mathrm{C}$ and $60 \mathrm{~min}$, while at milder torrefaction conditions of $200{ }^{\circ} \mathrm{C}$ and $15 \mathrm{~min}$, estimated values were $0.7,10$, and $17 \%$, for the same thermal degradation processes.

To evaluate the performance of the torrefaction process, the energy yield and the process energy efficiency (including process energy requirements) were determined and are detailed in Table 6.

Table 6. Energy yield, energy requirements, and process energy efficiency for the torrefaction of microalgae and lignocellulosic biomass.

\begin{tabular}{|c|c|c|c|c|c|c|c|c|c|c|c|c|}
\hline \multirow[b]{2}{*}{ Run } & \multicolumn{4}{|c|}{ Process Conditions } & \multirow{2}{*}{$\begin{array}{l}\text { Energy } \\
\text { Yield } \\
(\%)\end{array}$} & \multicolumn{6}{|c|}{ Energy Requirements } & \multirow{2}{*}{$\begin{array}{r}\text { PEE } \\
(\%)\end{array}$} \\
\hline & $\begin{array}{c}\mathrm{T} \\
\left({ }^{\circ} \mathrm{C}\right)\end{array}$ & $\begin{array}{l}\text { Time } \\
\text { (min) }\end{array}$ & $\begin{array}{c}\mathrm{M} \\
(\%)\end{array}$ & $\begin{array}{l}\text { Inc. } \\
(\%)\end{array}$ & & $\begin{array}{c}Q_{1} \\
(\mathbf{M J})\end{array}$ & $\begin{array}{c}Q_{2} \\
(\mathbf{M J})\end{array}$ & $\begin{array}{c}Q_{3} \\
(\mathbf{M J})\end{array}$ & $\begin{array}{c}Q_{4} \\
(\mathbf{M J})\end{array}$ & $\begin{array}{c}Q_{5} \\
(\mathbf{M J})\end{array}$ & $\begin{array}{l}Q_{\text {input }} \\
\text { (MJ) }\end{array}$ & \\
\hline 1 & 300 & 60 & 30 & 50 & 40.8 & 0.31 & 0.10 & 0.75 & 0.80 & 0.89 & 2.85 & 40.4 \\
\hline 2 & 300 & 60 & 15 & 25 & 53.0 & 0.38 & 0.06 & 0.41 & 0.55 & 0.63 & 2.02 & 52.6 \\
\hline 3 & 300 & 60 & 15 & 25 & 52.9 & 0.38 & 0.06 & 0.41 & 0.55 & 0.63 & 2.02 & 52.6 \\
\hline 4 & 300 & 45 & 45 & 0 & 36.0 & 0.24 & 0.15 & 1.08 & 0.90 & 1.01 & 3.37 & 35.6 \\
\hline 5 & 300 & 45 & 5 & 100 & 59.4 & 0.47 & 0.00 & 0.00 & 0.65 & 0.47 & 1.59 & 59.1 \\
\hline 6 & 300 & 45 & 5 & 50 & 59.7 & 0.45 & 0.01 & 0.06 & 0.65 & 0.50 & 1.66 & 59.4 \\
\hline 7 & 300 & 45 & 5 & 0 & 69.2 & 0.43 & 0.02 & 0.11 & 0.65 & 0.52 & 1.73 & 68.8 \\
\hline 8 & 300 & 30 & 30 & 50 & 56.6 & 0.35 & 0.07 & 0.54 & 1.00 & 0.79 & 2.75 & 56.1 \\
\hline 9 & 300 & 15 & 45 & 25 & 43.8 & 0.23 & 0.16 & 1.14 & 1.20 & 0.95 & 3.68 & 43.3 \\
\hline 10 & 300 & 15 & 45 & 0 & 45.0 & 0.24 & 0.15 & 1.08 & 1.20 & 0.93 & 3.60 & 44.5 \\
\hline 11 & 300 & 15 & 5 & 50 & 74.9 & 0.45 & 0.01 & 0.06 & 0.85 & 0.48 & 1.84 & 74.5 \\
\hline 12 & 275 & 60 & 70 & 0 & 26.3 & 0.14 & 0.21 & 1.51 & 0.80 & 1.13 & 3.78 & 26.0 \\
\hline 13 & 275 & 45 & 30 & 25 & 46.1 & 0.27 & 0.11 & 0.78 & 0.90 & 0.83 & 2.89 & 45.7 \\
\hline 14 & 250 & 60 & 15 & 0 & 65.6 & 0.28 & 0.07 & 0.54 & 0.60 & 0.60 & 2.10 & 65.2 \\
\hline 15 & 250 & 60 & 5 & 50 & 77.2 & 0.37 & 0.01 & 0.06 & 0.60 & 0.41 & 1.45 & 76.9 \\
\hline 16 & 250 & 45 & 30 & 50 & 47.4 & 0.25 & 0.10 & 0.75 & 1.10 & 0.83 & 3.04 & 47.0 \\
\hline 17 & 250 & 45 & 30 & 25 & 53.1 & 0.25 & 0.11 & 0.78 & 1.10 & 0.84 & 3.08 & 52.6 \\
\hline 18 & 250 & 45 & 30 & 25 & 51.8 & 0.25 & 0.11 & 0.78 & 1.10 & 0.84 & 3.08 & 51.3 \\
\hline 19 & 250 & 45 & 15 & 25 & 68.3 & 0.31 & 0.06 & 0.41 & 0.70 & 0.55 & 2.02 & 67.8 \\
\hline 20 & 250 & 45 & 15 & 25 & 67.6 & 0.31 & 0.06 & 0.41 & 0.70 & 0.55 & 2.02 & 67.2 \\
\hline 21 & 250 & 30 & 45 & 25 & 45.0 & 0.19 & 0.16 & 1.14 & 1.20 & 0.94 & 3.62 & 44.6 \\
\hline 22 & 250 & 30 & 45 & 25 & 45.3 & 0.19 & 0.16 & 1.14 & 1.20 & 0.94 & 3.62 & 44.8 \\
\hline 23 & 250 & 30 & 15 & 50 & 70.8 & 0.33 & 0.04 & 0.27 & 0.80 & 0.50 & 1.95 & 70.4 \\
\hline 24 & 250 & 30 & 5 & 25 & 86.6 & 0.36 & 0.01 & 0.08 & 0.80 & 0.44 & 1.70 & 86.2 \\
\hline 25 & 250 & 15 & 30 & 50 & 69.0 & 0.29 & 0.07 & 0.54 & 1.35 & 0.68 & 2.93 & 68.4 \\
\hline 26 & 250 & 15 & 5 & 0 & 92.4 & 0.36 & 0.02 & 0.11 & 0.90 & 0.42 & 1.80 & 91.9 \\
\hline 27 & 250 & 15 & 5 & 0 & 94.6 & 0.36 & 0.02 & 0.11 & 0.90 & 0.42 & 1.80 & 94.0 \\
\hline 28 & 225 & 60 & 5 & 25 & 89.5 & 0.32 & 0.01 & 0.08 & 0.65 & 0.40 & 1.47 & 89.1 \\
\hline
\end{tabular}


Table 6. Cont.

\begin{tabular}{|c|c|c|c|c|c|c|c|c|c|c|c|c|}
\hline \multirow{2}{*}{ Run } & \multicolumn{4}{|c|}{ Process Conditions } & \multirow{2}{*}{$\begin{array}{l}\text { Energy } \\
\text { Yield } \\
(\%)\end{array}$} & \multicolumn{6}{|c|}{ Energy Requirements } & \multirow{2}{*}{$\begin{array}{l}\text { PEE } \\
(\%)\end{array}$} \\
\hline & $\begin{array}{c}\mathrm{T} \\
\left({ }^{\circ} \mathrm{C}\right)\end{array}$ & $\begin{array}{l}\text { Time } \\
\text { (min) }\end{array}$ & $\begin{array}{c}M \\
(\%)\end{array}$ & $\begin{array}{l}\text { Inc. } \\
(\%)\end{array}$ & & $\begin{array}{c}Q_{1} \\
(\mathbf{M J})\end{array}$ & $\begin{array}{c}Q_{2} \\
(\mathbf{M J})\end{array}$ & $\begin{array}{c}Q_{3} \\
(\mathbf{M J})\end{array}$ & $\begin{array}{c}Q_{4} \\
(\mathrm{MJ})\end{array}$ & $\begin{array}{c}Q_{5} \\
(\mathbf{M J})\end{array}$ & $\begin{array}{l}Q_{\text {input }} \\
\text { (MJ) }\end{array}$ & \\
\hline 29 & 225 & 45 & 45 & 0 & 47.6 & 0.17 & 0.15 & 1.08 & 1.30 & 0.95 & 3.65 & 47.1 \\
\hline 30 & 225 & 15 & 15 & 25 & 68.5 & 0.27 & 0.06 & 0.41 & 0.95 & 0.46 & 2.15 & 68.0 \\
\hline 31 & 200 & 60 & 45 & 25 & 46.3 & 0.15 & 0.16 & 1.14 & 1.20 & 0.92 & 3.56 & 45.8 \\
\hline 32 & 200 & 60 & 30 & 50 & 63.8 & 0.22 & 0.07 & 0.54 & 1.20 & 0.71 & 2.75 & 63.3 \\
\hline 33 & 200 & 60 & 5 & 0 & 99.8 & 0.28 & 0.02 & 0.11 & 0.70 & 0.39 & 1.49 & 99.3 \\
\hline 34 & 200 & 30 & 15 & 25 & 83.1 & 0.24 & 0.06 & 0.41 & 0.90 & 0.48 & 2.08 & 82.5 \\
\hline 35 & 200 & 30 & 15 & 25 & 78.8 & 0.24 & 0.06 & 0.41 & 0.90 & 0.48 & 2.08 & 78.3 \\
\hline 36 & 200 & 30 & 5 & 50 & 93.1 & 0.29 & 0.01 & 0.06 & 0.90 & 0.38 & 1.63 & 92.7 \\
\hline 37 & 200 & 15 & 70 & 0 & 58.1 & 0.10 & 0.21 & 1.51 & 1.50 & 0.83 & 4.14 & 57.3 \\
\hline 38 & 200 & 15 & 30 & 50 & 68.0 & 0.20 & 0.10 & 0.75 & 1.50 & 0.64 & 3.19 & 67.4 \\
\hline 39 & 200 & 15 & 30 & 25 & 73.8 & 0.19 & 0.11 & 0.78 & 1.50 & 0.65 & 3.23 & 73.1 \\
\hline
\end{tabular}

The energy yield, expressed as the amount of energy contained in the raw material that is retained in the biochar, reached the highest value $(99.8 \%)$ at $200{ }^{\circ} \mathrm{C}, 60 \mathrm{~min}, 5 \%$ moisture, and $0 \%$ lignocellulosic material incorporation. Energy yield decreased with increasing temperature and moisture because both parameters were negatively correlated with biochar yield. According to Zhang et al. [51], biochars produced by torrefaction of microalgae residues (1.8\% moisture) had energy yields that ranged from $77 \%\left(300{ }^{\circ} \mathrm{C}\right.$ and $\left.60 \mathrm{~min}\right)$ to $93 \%$ $\left(200{ }^{\circ} \mathrm{C}\right.$ and $\left.15 \mathrm{~min}\right)$ in a nitrogen environment. In the present study, comparable energy yields were obtained for feedstocks with $5 \%$ or $15 \%$ of initial moisture and temperatures up to $250{ }^{\circ} \mathrm{C}$. At higher temperatures, the biochar yields obtained were lower than $70 \%$, probably because torrefaction was performed in oxygen-deficient conditions but not under a nitrogen flow, which limits autothermal decomposition reactions.

The determination of the heat requirements is challenging because there are considerable differences in the magnitude of thermal losses, in the specific heat of raw materials and the heat of reaction, depending on the configurations and dimensions of the reactors [67]. $Q_{1}$ (energy required for feedstock heating) increases with increasing process temperature. In this study, there was also an increase in $Q_{1}$ when the feedstock was mostly lignocellulosic material, with a when algal biomass was incorporated because the $C p$ of lignocellulosic material is higher ( $C p$ lignocellulosic $\left.=1.7 \mathrm{KJ} \mathrm{Kg}^{-1} \mathrm{~K}^{-1}[68]\right)$ than that of algal biomass (Cp microalgae $\left.=1.58 \mathrm{KJ} \mathrm{Kg}^{-1} \mathrm{~K}^{-1}[69]\right) . Q_{2}$ and $Q_{3}$, which are energy requirements for heating and evaporation of the water in the system [45], increased with moisture. $Q_{4}$ is the heat of reaction that decreases with the increasing temperature and residence time because the magnitude of exothermic reactions is increased by the process severity [38]. $Q_{5}$ represents thermal losses, and it increases with the process temperature and residence time. The thermal losses were evaluated as in Nobre et al. [45]. The PEE and energy yield were higher in mild torrefaction conditions because, under these conditions, less mass loss occurred. However, the HHVs of these biochars were lower because of their high $\mathrm{O} / \mathrm{C}$ and $\mathrm{H} / \mathrm{C}$ ratios, and therefore their fuel quality was negatively affected.

The relation between the torrefaction process energy efficiency (PEE, \%) and the high heating value of the produced biochars $\left(\mathrm{HHV}, \mathrm{MJ} \mathrm{Kg}{ }^{-1}\right)$ is represented in Figure 3.

For the energy valorization pathway to be viable, it is necessary to choose conditions in which the process energy efficiency is higher than $50 \%$, that is, the energy recovered in the products is higher than the sum of the process energy with the heat of combustion of the feedstock. On the other hand, to produce a biochar with a good fuel quality, process conditions that lead to biochars with the highest HHV should be selected.

As seen in Figure 3, the biochars produced at $200{ }^{\circ} \mathrm{C}$ and $250{ }^{\circ} \mathrm{C}$ presented HHVs lower than $18 \mathrm{MJ} \mathrm{Kg}^{-1}$, regardless of the corresponding PEE value, while at $300{ }^{\circ} \mathrm{C}$, it was possible to obtain biochars with HHVs higher than $18 \mathrm{MJ} \mathrm{Kg}^{-1}$ for most conditions tested and particularly for PEE values higher than $60 \%$. 


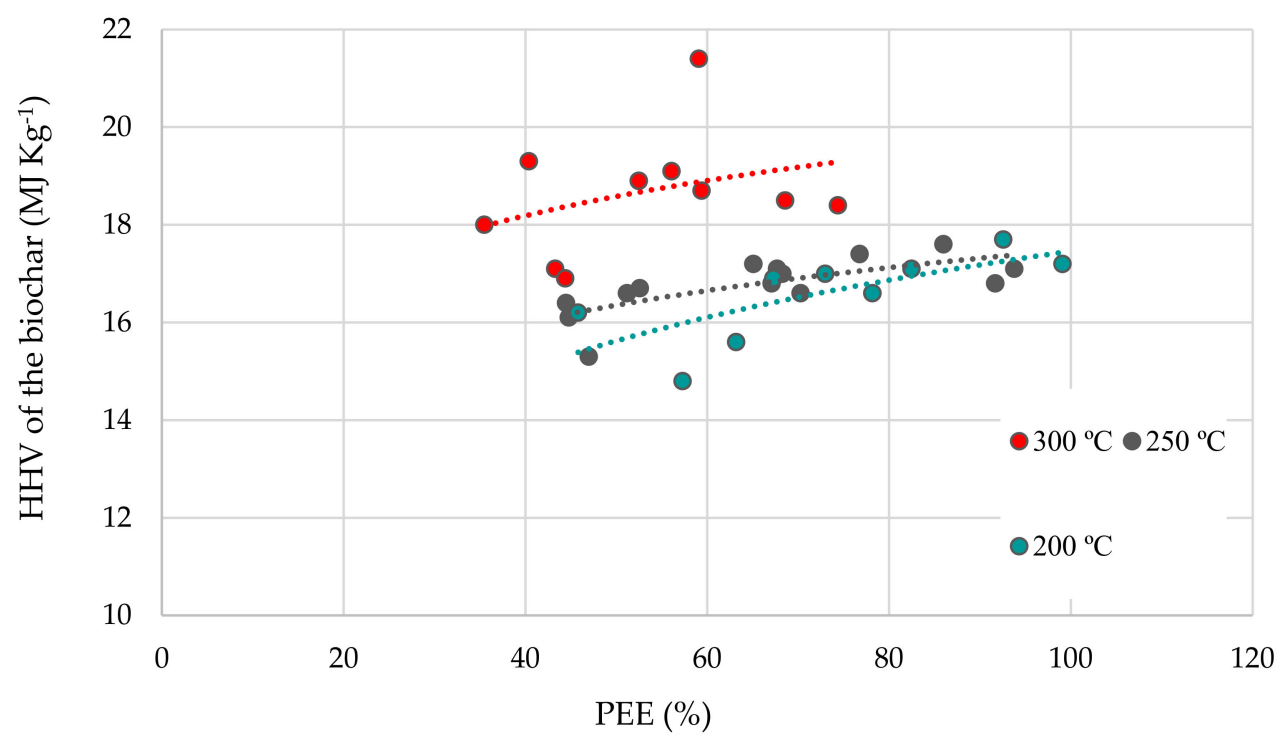

Figure 3. High heating value of biochar $\left(\mathrm{MJ} \mathrm{Kg}^{-1}\right)$ as a function of the process energy efficiency for experiments performed at different temperatures, residence times, initial moisture, and Lc incorporation rate.

\subsection{Response Surface Methodology (RSM) Analysis}

RSM has been widely applied to process improvement and optimization, reducing the number of experimental runs needed to evaluate the influence of several independent variables in the critical properties to be studied [70]. For the quadratic model suggested by the RSM, the non-significant terms, with $p>0.05$ (except those that support the modelnon-significant linear terms: A, B, C, D) were removed. This operation resulted in a reduced equation for each answer, which describes the adjustment to the experimental data. The equations for product yields with significant terms are found in (Supplementary Materials) and for biochar characterization in Table S3 (Supplementary Materials). The equations for process performance and HHV are presented in Table 7, except for $Q_{\text {input }}$ and $Q_{\text {output }}$ (Table S4, Supplementary Materials).

Table 7. Equations generated by RSM software, with $R^{2}$, Adjusted $R^{2}$, Predicted $R^{2}$ and Adequate Precision for $H H V$ and energy and mass balances.

\begin{tabular}{|c|c|c|c|c|c|c|}
\hline Parameter & Equation ** & F-Value & $\mathbf{R}^{2}$ & Adjusted $\mathbf{R}^{2}$ & Predicted $\mathbf{R}^{2}$ & $\begin{array}{l}\text { Adequate } \\
\text { Precision }\end{array}$ \\
\hline $\mathrm{HHV}$ & $\begin{array}{l}31.76-0.12 \mathrm{~T}-0.11 \mathrm{t}-0.12 \mathrm{M}+0.06 \mathrm{I} \\
+4.20 \times 10^{-4}(\mathrm{~T} \times \mathrm{t})+3.34 \times 10^{-4}(\mathrm{~T} \times \\
\mathrm{M})-2.83 \times 10^{-4}(\mathrm{~T} \times \mathrm{I})+5.28 \times 10^{-4} \\
\quad(\mathrm{t} \times \mathrm{M})+2.77 \times 10^{-4}\left(\mathrm{~T}^{2}\right)\end{array}$ & 31.42 & 0.916 & 0.887 & 0.794 & 29.224 \\
\hline Mass yield & $\begin{array}{c}47.22+0.91 \mathrm{~T}-0.73 \mathrm{t}-2.07 \mathrm{M}-0.52 \mathrm{I} \\
+6.03 \times 10^{-3}(\mathrm{~T} \times \mathrm{M})-3.42 \times 10^{-3}(\mathrm{~T} \\
\times \mathrm{I})-9.73 \times 10^{-3}(\mathrm{t} \times \mathrm{M})+5.74 \times \\
10^{-3}(\mathrm{t} \times \mathrm{I})-2.06 \times 10^{-3}\left(\mathrm{~T}^{2}\right)+3.31 \times \\
10^{-3}\left(\mathrm{t}^{2}\right)+8.25 \times 10^{-3}\left(\mathrm{I}^{2}\right)\end{array}$ & 778.33 & 0.998 & 0.997 & 0.992 & 95.136 \\
\hline $\begin{array}{c}\text { Energy } \\
\text { yield }\end{array}$ & $\begin{array}{c}79.50+0.53 \mathrm{~T}-1.91 \mathrm{t}-3.15 \mathrm{M}+0.74 \mathrm{I} \\
+1.79 \times 10^{-3}(\mathrm{~T} \times \mathrm{t})+5.78 \times 10^{-3}(\mathrm{~T} \times \\
\mathrm{M})-2.66 \times 10^{-3}(\mathrm{~T} \times \mathrm{I})+3.83 \times 10^{-3}(\mathrm{t} \\
\times \mathrm{I})-1.50 \times 10^{-3}\left(\mathrm{~T}^{2}\right)+0.01\left(\mathrm{t}^{2}\right)+0.02 \\
\left(\mathrm{M}^{2}\right)-9.26 \times 10^{-3}\left(\mathrm{I}^{2}\right)\end{array}$ & 135.92 & 0.988 & 0.981 & 0.955 & 39.672 \\
\hline
\end{tabular}


Table 7. Cont.

\begin{tabular}{|c|c|c|c|c|c|c|}
\hline Parameter & Equation ** & F-Value & $\mathbf{R}^{2}$ & Adjusted $\mathbf{R}^{2}$ & Predicted $R^{2}$ & $\begin{array}{l}\text { Adequate } \\
\text { Precision }\end{array}$ \\
\hline PEE & $\begin{array}{c}80.40+0.51 \mathrm{~T}-1.49 \mathrm{t}-2.58 \mathrm{M}+0.29 \mathrm{I}+ \\
4.28 \times 10^{-3}(\mathrm{~T} \times \mathrm{M})-1.50 \times 10^{-3}(\mathrm{~T} \\
\times \mathrm{I})+5.59 \times 10^{-3}(\mathrm{t} \times \mathrm{I})-1.40 \times 10^{-3} \\
\left(\mathrm{~T}^{2}\right)+0.01\left(\mathrm{t}^{2}\right)+0.01\left(\mathrm{M}^{2}\right)\end{array}$ & 180.82 & 0.988 & 0.983 & 0.963 & 45.512 \\
\hline
\end{tabular}

Note: $p$-value model is always $0.01 \%$, and it means that there is only a $0.01 \%$ chance that an F-value this large could occur due to noise. The lack of fit is not significant $(<4) .{ }^{* *}$ Where $\mathrm{T}, \mathrm{t}, \mathrm{M}$, and I mean temperature, residence time, moisture, and incorporation rate of algal sludge, respectively.

For all the analyzed responses, $\mathrm{R}^{2}$, adjusted $\mathrm{R}^{2}$, and predicted $\mathrm{R}^{2}$ were high and the difference between adjusted $R^{2}$ and predicted $R^{2}$ was less than 0.2 , which suggests a good fit of the model to the obtained data. $\mathrm{R}^{2}$ (coefficient of determination) represents the ratio of the total changes in the predicted response. The adequate precision measures the signal to noise ratio and has values well above 4 , which is the minimum desirable value.

To study how the different variables interact in the process and their effects on the response (energy yield and HHV), three-dimensional (3D) response surface plots were made for any two independent process variables, keeping the others at their average level. Figures 4 and 5 present the 3D surface plots with the interactions between the energy yield and HHV and their respective output responses.

Energy yield was higher for lower temperatures and residence times (Figure 4), especially when associated with low values of feedstock moisture and Lc incorporation rate; this behavior reflects the influence of the biochar mass yield on the energy yield. The negative correlation of the energy yield with initial moisture and Lc incorporation rate is corroborated in Figure 4E,F for different torrefaction temperatures.

When looking at the influence of the different variables and the interactions between the variable pairs, it is possible to conclude that the HHV of the biochar (Figure 5) is positively correlated with the torrefaction temperature and negatively correlated with the feedstock moisture, while time and Lc incorporation rate have less influence on this parameter.

Increasing temperature has the effect of increasing the thermochemical decomposition and of removing oxygen and nitrogen, favoring the formation of aromatic carbonaceous structures, but reducing biochar yield. In contrast, the increase in residence time favors the carbon content biochar yield because it benefits reactions of recombination and adsorption to the biochar itself. The water content always removes energy from the reaction, but it can have a hydrothermal effect as it is an oxidizing agent. Comparing Figure $4 A, B$, the negative effect of introducing more water is visible.

HHV increased with the incorporation of lignocellulosic biomass for low temperatures but followed an opposite trend at high temperatures. These different behaviors may result from a higher degree of aromatization of the Lc biomass at temperatures above the cellulose and hemicellulose thermal decomposition threshold. The increase in water content decreased the HHV of the obtained biochar, but this decrease was only evident for the most severe torrefaction conditions (Figure 5A,B); in the case of low temperatures, regardless of residence time, the biochars' HHV was not affected by the addition of water. 

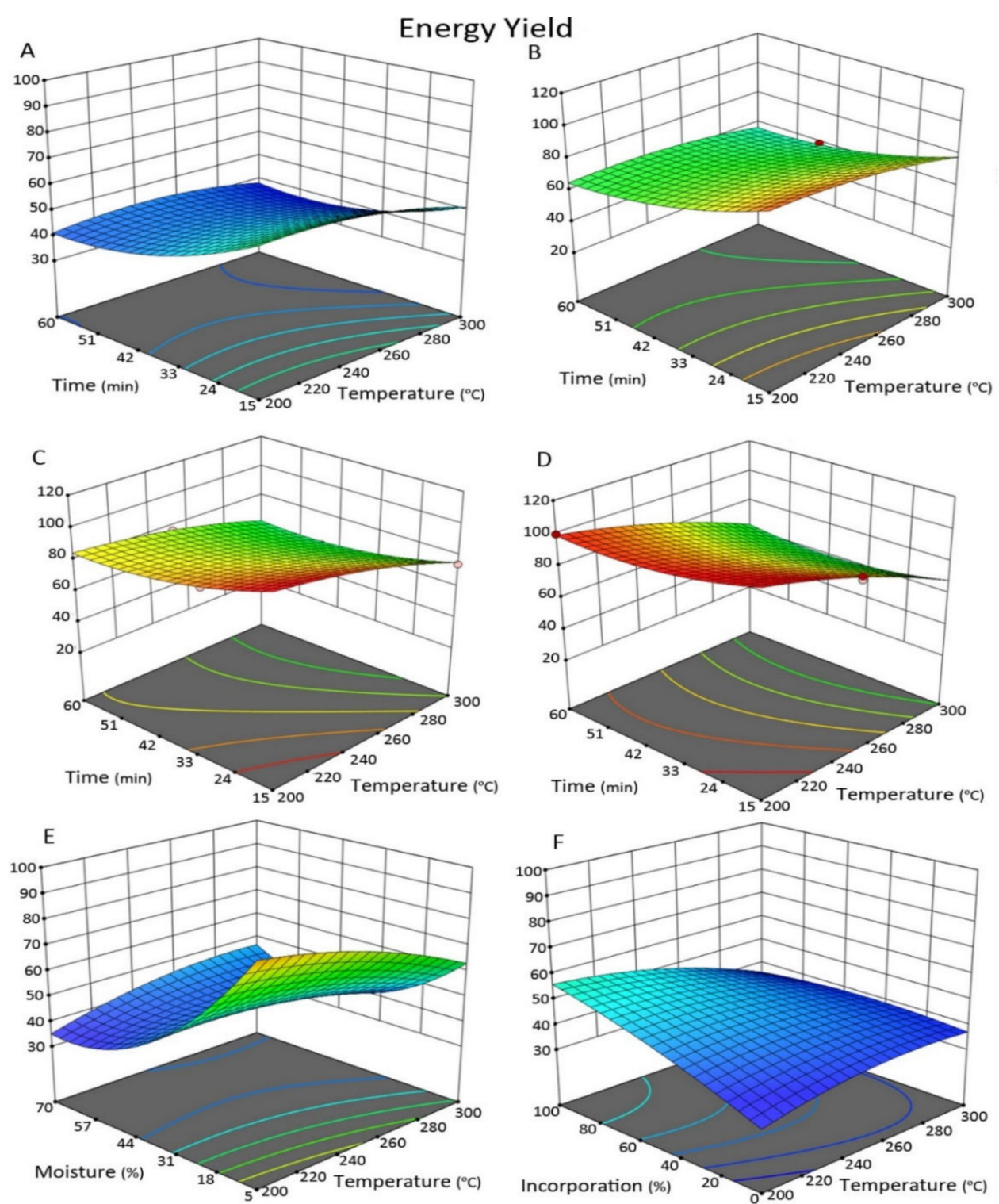

Figure 4. Relation between energy yield and the interaction terms by 3D plot: (A) interaction between $\mathrm{T} \times \mathrm{t}(\mathrm{M}=37.5 \%$ and $\mathrm{I}=50 \%),(\mathrm{B})$ interaction between $\mathrm{T} \times \mathrm{t}(\mathrm{M}=5 \%$ and $\mathrm{I}=100 \%) ;(\mathrm{C})$ interaction between $\mathrm{T} \times \mathrm{t}(\mathrm{M}=5 \%$ and $\mathrm{I}=50 \%)$; (D) interaction between $\mathrm{T} \times \mathrm{t}(\mathrm{M}=5 \%$ and $\mathrm{I}=0 \%)$; $(\mathrm{E})$ interaction between $\mathrm{T} \times \mathrm{M}(\mathrm{t}=30 \mathrm{~min}$ and $\mathrm{I}=50 \%)$; and $(\mathrm{F})$ interaction between $\mathrm{T} \times \mathrm{I}(\mathrm{M}=37.5 \%$ and $\mathrm{t}=30 \mathrm{~min})$, $\mathrm{T}$ - torrefaction temperature, $\mathrm{t}$ - time, $\mathrm{M}$-feedstock moisture, $\mathrm{I}$ - $\mathrm{Lc}$ incorporation rate. 

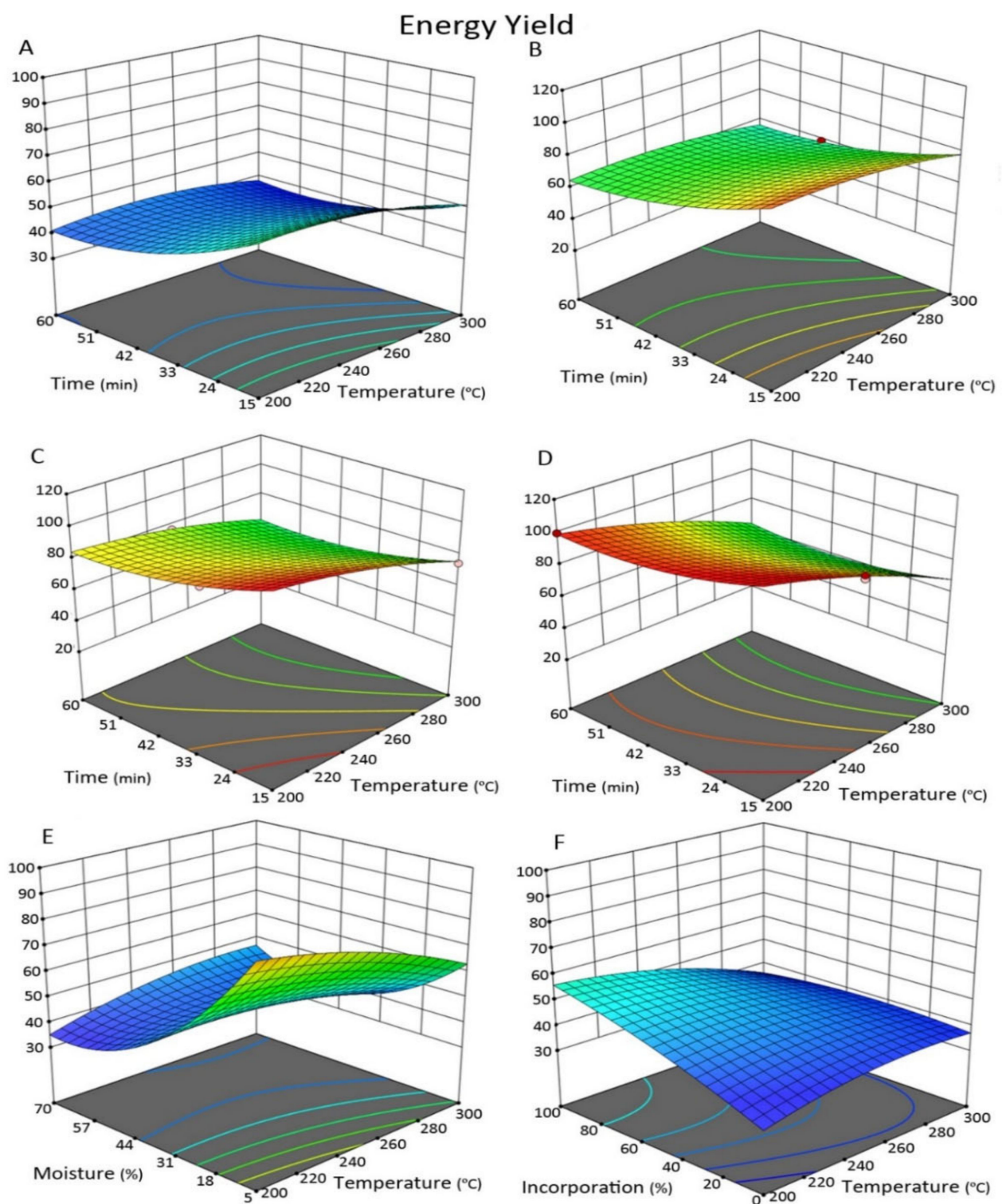

Figure 5. Relation between HHV and the interaction terms by 3D plot: (A) interaction between $\mathrm{T} \times \mathrm{t}(\mathrm{M}=37.5 \%$ and $\mathrm{I}=50 \%),(\mathrm{B})$ interaction between $\mathrm{T} \times \mathrm{t}(\mathrm{M}=5 \%$ and $\mathrm{I}=0 \%) ;(\mathrm{C})$ interaction between $\mathrm{T} \times \mathrm{t}(\mathrm{M}=37.5 \%$ and $\mathrm{I}=100 \%) ;$ (D) interaction between $\mathrm{T} \times \mathrm{t}(\mathrm{M}=70 \%$ and $\mathrm{I}=0 \%)$; (E) interaction between $\mathrm{T} \times \mathrm{M}(\mathrm{t}=30 \mathrm{~min}$ and $\mathrm{I}=50 \%)$; and $(\mathrm{F})$ interaction between $\mathrm{T} \times \mathrm{I}(\mathrm{M}=37.5 \%$ and $\mathrm{t}=30 \mathrm{~min})$, $\mathrm{T}$ - torrefaction temperature, $\mathrm{t}$ - time, $\mathrm{M}$-feedstock moisture, $\mathrm{I}$ - $\mathrm{Lc}$ incorporation rate.

\subsection{Biochars from Wastewater Microalgae Biomass}

To evaluate the effect of torrefaction on algal biomass produced in contaminated effluents (aquaculture wastewaters and landfill leachate), biomass samples from Chlorella vulgaris grown in these effluents were used as torrefaction feedstocks with and without the addition of lignocellulosic material. For these experiments, the product yields were determined, and the biochar samples were characterized. Table 8 presents the product yields, proximate analysis, high heating value (HHV), and adsorption capacity of the produced biochar samples. 
Table 8. Yields of torrefaction products and characterization of produced biochar.

\begin{tabular}{|c|c|c|c|c|c|c|}
\hline & & Cv-Aquac. & Cv-Leachate & Cv-Aquac. + Lc & Cv-Leach. + Lc & Lc \\
\hline \multirow{6}{*}{$\begin{array}{c}\text { Mass Yield } \\
(\%)\end{array}$} & Biochar & $73.7 \pm 0.5$ & $84.2 \pm 1.5$ & $74.0 \pm 1.1$ & $78.6 \pm 1.7$ & $73.0 \pm 1.4$ \\
\hline & Condensates & $19.4 \pm 2.0$ & $11.5 \pm 1.7$ & $18.9 \pm 1.2$ & $16.2 \pm 1.6$ & $21.0 \pm 0.8$ \\
\hline & Gases & $6.9 \pm 1.4$ & $4.4 \pm 0.2$ & $7.2 \pm 0.1$ & $5.2 \pm 0.1$ & $6.0 \pm 0.6$ \\
\hline & Ash content (wt. $\%, \mathrm{db})$ & $33.5 \pm 0.8$ & $65.5 \pm 0.3$ & $17.3 \pm 0.8$ & $34.6 \pm 0.4$ & $3.8 \pm 0.3$ \\
\hline & Volatile matter (wt.\%, db) & $56.8 \pm 1.1$ & $31.0 \pm 0.5$ & $66.1 \pm 0.6$ & $56.1 \pm 0.6$ & $81.2 \pm 1.1$ \\
\hline & Fixed carbon $(w t . \%, d b)$ & $9.6 \pm 1.4$ & $3.6 \pm 0.1$ & $16.6 \pm 0.3$ & $9.3 \pm 0.4$ & $15.1 \pm 0.9$ \\
\hline Biochar & $\mathrm{HHV}\left(\mathrm{MJ} \mathrm{Kg}{ }^{-1}\right)(\mathrm{db})$ & 12.0 & 5.6 & 16.0 & 11.8 & 18.0 \\
\hline \multirow[t]{4}{*}{ Characterization } & $\mathrm{O} / \mathrm{C}$ ratio (daf) & $0.31 \pm 0.0$ & $0.44 \pm 0.0$ & $0.44 \pm 0.0$ & $0.54 \pm 0.0$ & $0.57 \pm 0.0$ \\
\hline & $\mathrm{H} / \mathrm{C}$ ratio (daf) & $1.28 \pm 0.0$ & $1.65 \pm 0.0$ & $1.34 \pm 0.0$ & $1.37 \pm 0.0$ & $1.27 \pm 0.0$ \\
\hline & Adsorption & $35.7 \pm 0.7$ & $45.7 \pm 0.9$ & $32.8 \pm 1.2$ & $30.5 \pm 1.8$ & $16.4 \pm 1.7$ \\
\hline & capacity $(\%)$ & $56.5 \pm 0.5$ & $58.1 \pm 2.1$ & $52.3 \pm 1.9$ & $46.5 \pm 1.5$ & $36.8 \pm 0.8$ \\
\hline
\end{tabular}

Note: Cv-Aquac.: $10 \mathrm{~g}$ of Chlorella vulgaris from aquaculture effluents; Cv-Leachate: $10 \mathrm{~g}$ of Chlorella vulgaris grown in landfill leachate effluent; Cv-Aquac. + Lc: $5 \mathrm{~g}$ of C. vulgaris from aquaculture $+5 \mathrm{~g}$ of Lc; Cv-Leach. + Lc: $5 \mathrm{~g}$ of C. vulgaris from leachate $+5 \mathrm{~g}$ of Lc; Lc: $10 \mathrm{~g}$ of lignocellulosic material.

Biochar yields varied in the range of $73.0 \%$ to $84.2 \%$ and were comparable for the torrefaction of $C$. vulgaris $(\mathrm{Cv})$ biomass grown in contaminated effluents, mixtures of those biomasses with $50 \% \mathrm{Lc}$, or the lignocellulosic material alone $(100 \% \mathrm{Lc})$. When the feed included $\mathrm{Cv}$ biomass produced in landfill leachate, the biochar yield was higher (79\% and $84 \%)$ than for the tests using $\mathrm{Cv}$ grown in aquaculture effluents, which may reflect the accumulation of non-volatile contaminants of the landfill leachate in the microalgae biomass.

On the other hand, condensate yield and gas products yields were higher for the tests including $\mathrm{Cv}$ biomass grown in aquaculture effluents or $100 \% \mathrm{Lc}$, indicating a higher abundance of organic volatile components in these feedstocks.

These observations agree with the high ash contents detected in Cv-leachate biochar, an indication that mineral components from the landfill leachate were bioaccumulated in the algal biomass. The high concentration of minerals associated with a low content of fixed carbon resulted in an HHV of only $5.6 \mathrm{MJ} / \mathrm{kg}$ for this biochar.

The Cv aquaculture biochar had lower ash content and higher concentrations of volatile matter and fixed carbon mixture, which resulted in an $\mathrm{HHV}$ of $12.0 \mathrm{MJ} / \mathrm{kg}$, significantly higher than that of the $\mathrm{Cv}$-leachate biochar. These results indicate that not only the nature of the microalgae but also the composition of the effluent may have a strong influence on the composition of the algal biomass and consequently the yield and composition of the correspondent biochar. In both cases, the incorporation of $50 \%$ Lc material had a positive effect on the fuel quality of the biochars by reducing ash content and increasing volatile matter, fixed carbon, and HHV.

Microalgae produced in landfill leachate usually have a high amount of ash in their biomass [3]. This occurs because these organisms tend to assimilate minerals from the environment inside their cells and landfill leachate has a high mineral concentration [71]. Also, microalgae produced in saltwater (or aquaculture effluents) tend to have a high ash content, as found by Fakayode et al. [72].

The $\mathrm{O} / \mathrm{C}$ and $\mathrm{H} / \mathrm{C}$ ratios of raw materials ( 0.47 and 1.21 for algae and 1.71 and 1.51 for lignocellulosic biomass, respectively) were reduced with the torrefaction process, giving rise to a biochar with characteristics close to lignite and better than a peat. The torrefaction process is considered an upgrading process, because it increases the hydrophobicity and the energy density of the torrefied material and reduces the need for biomass grinding energy [61]. The production of biochar from microalgae has the advantage of greater stability and density of the final material, which also translates into lower transport costs [72]. Furthermore, it results in a material that can be easily used in agriculture as a soil amendment, releasing nutrients ( $\mathrm{N}$ and $\mathrm{P}$ ) slowly into the soil due to the presence of functional groups with oxygen on the surface of the biochar.

These biochars also reveal potential to be further explored as bioadsorbents reaching an adsorption capacity value for $\mathrm{MB}$ of $58.1 \%$, without any activation process. Some experiments have revealed that torrefied algal biomass has a quite different structure than 
that of the original microalgae, becoming irregular and compact, which tends to increase its adsorption capacity [73]. In addition, the biomass that originated the biochars had already treated a landfill leachate or an aquaculture effluent, and thus this process can be integrated into a circular economy concept.

\section{Conclusions}

Torrefaction can be seen as a process with low energy requirements resulting in a biochar that is more stable and denser when compared to the original feedstock. Biochars have several applications, including energy valorization, soil amendment, and bioremediation of contaminated effluents.

In this work, RSM has proven to be a useful tool to optimize process parameters observed in the experimental data. A quadratic model has been recommended as a good model for predicting the production of biochar with high calorific value.

Moreover, the conditions that lead to greater biochar production with increased HHV were $250{ }^{\circ} \mathrm{C}, 60 \mathrm{~min}$ of residence time, 5\% moisture, and 50\% lignocellulosic biomass as feedstock. However, the incorporation of lignocellulosic biomass had more influence on $\mathrm{HHV}$ and fixed carbon content rather than on biochar yield. Mixing algal biomass with lignocellulosic biomass was shown to be beneficial by improving the quality of the obtained biochars. Under optimum conditions, it is possible to obtain a biochar yield of $76.5 \%$ with an $\mathrm{HHV}$ of $17.4 \mathrm{MJ} \mathrm{Kg}^{-1}$.

Results showed that it is feasible to lower the torrefaction temperature to $250{ }^{\circ} \mathrm{C}$ without significantly affecting biochar yield and quality, provided that the residence time is maintained at $60 \mathrm{~min}$. Alternatively, it is also possible to reduce residence time to $30 \mathrm{~min}$, maintaining the temperature at $300^{\circ} \mathrm{C}$, without significantly affecting biochar yields.

Adding water to the feedstock considerably reduces the efficiency of the torrefaction process. Therefore, for biomass with higher moisture levels, a greater amount of lignocellulosic biomass should be incorporated to compensate for this issue.

The evaluation of the torrefaction process performance showed that using moderate torrefaction conditions (temperature and residence time) leads to better energy performance of the process with higher mass yields. However, biochars obtained under these conditions have lower $\mathrm{HHV}$ because of the high $\mathrm{O} / \mathrm{C}$ and $\mathrm{H} / \mathrm{C}$ ratios, so their fuel qualities were not enhanced.

Biochars produced in this work presented good adsorption capacities towards MB. Furthermore, the use of microalgae previously used in effluent treatment as feedstock in biochar production, also present good adsorption capacities compared to biochars obtained from commercial algal biomass. However, these algal biomass samples usually present a high levels of salts (situation verified for microalgae produced in aquaculture effluent and landfill leachate), and as such, the obtained biochars presented high ash contents resulting in a decrease in their HHV. Even with lower HHVs than those of the model biochar samples, these biochars can be used as low-cost adsorbents and further studies should be conducted to validate their use in soil amendment applications.

Supplementary Materials: The following are available online at https: / www.mdpi.com/article / 10.3390/en14217330/s1, Table S1: Experimental design matrix using the RSM modeling technique, Table S2: Equations generated by RSM software, with R2, adjusted $R^{2}$, predicted $R^{2}$, and adequate precision for product yields; Table S3: Equations generated by RSM software, with R2, Adjusted $\mathrm{R}^{2}$, Predicted $\mathrm{R}^{2}$ and Adequate Precision for biochar characterization; Table S4: Equations generated by RSM software, with $R 2$, adjusted $R^{2}$, predicted $R^{2}$, and adequate precision for energy densification index, Qinput and Qoutput.

Author Contributions: Conceptualization, C.V. and M.G.; methodology, C.V. and M.G.; validation, C.N., R.C. and M.G.; formal analysis, C.V.; investigation, C.V.; resources, M.G.; data curation, C.V., M.G. and C.N.; writing-original draft preparation, C.V.; writing-review and editing, C.V., M.G., C.N., R.C. and L.G.; supervision, M.G.; funding acquisition, M.G. All authors have read and agreed to the published version of the manuscript. 
Funding: This research was funded by Fundação para a Ciência e Tecnologia, Portugal, grant number SFRH/BD/131178/2017 and the R\&D Units Project Scope UIDP/04077/2020.

Informed Consent Statement: Not applicable.

Conflicts of Interest: The authors declare no conflict of interest. The funders had no role in the design of the study; in the collection, analyses, or interpretation of data; in the writing of the manuscript, or in the decision to publish the results.

\section{References}

1. Apandi, N.M.; Mohamed, R.M.S.R.; Al-Gheethi, A.; Kassim, A.H.M. Microalgal biomass production through phycoremediation of fresh market wastewater and potential applications as aquaculture feeds. Environ. Sci. Pollut. Res. 2019, 26, 3226-3242. [CrossRef] [PubMed]

2. Viegas, C.; Gonçalves, M. Integrated Treatment of Pig Production Wastewaters Using Pre-treatment with Biomass Ash and Bioremediation by Microalgae. Acta Sci. Agric. 2021, 5, 44-57. [CrossRef]

3. Viegas, C.; Nobre, C.; Mota, A.; Vilarinho, C.; Gouveia, L.; Gonçalves, M. A circular approach for landfill leachate treatment: Chemical precipitation with biomass ash followed by bioremediation through microalgae. J. Environ. Chem. Eng. 2021, 9, 105187. [CrossRef]

4. Viegas, C.; Gouveia, L.; Gonçalves, M. Aquaculture wastewater treatment through microalgal. Biomass potential applications on animal feed, agriculture, and energy. J. Environ. Manag. 2021, 286, 112187. [CrossRef] [PubMed]

5. Porto, B.; Gonçalves, A.L.; Esteves, A.F.; de Souza, S.M.A.G.U.; de Souza, A.A.U.; Vilar, V.J.P.; Pires, J.C.M. Assessing the potential of microalgae for nutrients removal from a landfill leachate using an innovative tubular photobioreactor. Chem. Eng. J. 2020, 413, 127546. [CrossRef]

6. Loulergue, P.; Balannec, B.; Fouchard-Le Graët, L.; Cabrol, A.; Sayed, W.; Djelal, H.; Amrane, A.; Szymczyk, A. Air-gap membrane distillation for the separation of bioethanol from algal-based fermentation broth. Sep. Purif. Technol. 2019, 213, 255-263. [CrossRef]

7. Lucakova, S.; Branyikova, I.; Kovacikova, S.; Pivokonsky, M.; Filipenska, M.; Branyik, T.; Ruzicka, M.C. Electrocoagulation reduces harvesting costs for microalgae. Bioresour. Technol. 2021, 323, 124606. [CrossRef]

8. Visigalli, S.; Barberis, M.G.; Turolla, A.; Canziani, R.; Zrimec, M.B.; Reinhardt, R.; Ficara, E. Electrocoagulation-flotation (ECF) for microalgae harvesting-A review. Sep. Purif. Technol. 2021, 271, 118684. [CrossRef]

9. Carvalho, J.C.; Magalhães, A.I.; Pereira, G.M.; Medeiros, A.B.; Sydney, E.B.; Rodrigues, C.; Aulestia, D.; Vandenberghe, L.P.; Soccol, V.T.; Soccol, C.R. Microalgal biomass pretreatment for integrated processing into biofuels, food, and feed. Bioresour. Technol. 2020, 300, 122719. [CrossRef]

10. Rao, N.; Granville, A.M.; Browne, C.I.; Dagastine, R.R.; Yap, R.; Jefferson, B.; Henderson, R.K. Determining how polymer-bubble interactions impact algal separation using the novel "Posi"-dissolved air flotation process. Sep. Purif. Technol. 2018, 201, 139-147. [CrossRef]

11. Wahlen, B.D.; Wendt, L.M.; Murphy, A.; Thompson, V.S.; Hartley, D.S.; Dempster, T.; Gerken, H. Preservation of Microalgae, Lignocellulosic Biomass Blends by Ensiling to Enable Consistent Year-Round Feedstock Supply for Thermochemical Conversion to Biofuels. Front. Bioeng. Biotechnol. 2020, 8, 316. [CrossRef]

12. Hosseinizand, H.; Sokhansanj, S.; Lim, C.J. Co-pelletization of microalgae Chlorella vulgaris and pine sawdust to produce solid fuels. Fuel Process. Technol. 2018, 177, 129-139. [CrossRef]

13. Choi, H.I.; Lee, J.S.; Choi, J.W.; Shin, Y.S.; Sung, Y.J.; Hong, M.E.; Kwak, H.S.; Kim, C.Y.; Sim, S.J. Performance and potential appraisal of various microalgae as direct combustion fuel. Bioresour. Technol. 2019, 273, 341-349. [CrossRef]

14. Lee, J.; Sohn, D.; Lee, K.; Park, K.Y. Solid fuel production through hydrothermal carbonization of sewage sludge and microalgae Chlorella sp. from wastewater treatment plant. Chemosphere 2019, 230, 157-163. [CrossRef]

15. Wu, K.T.; Tsai, C.J.; Chen, C.S.; Chen, H.W. The characteristics of torrefied microalgae. Appl. Energy 2012, 100, 52-57. [CrossRef]

16. Wang, J.; Peng, X.; Chen, X.; Ma, X. Co-liquefaction of low-lipid microalgae and starch-rich biomass waste: The interaction effect on product distribution and composition. J. Anal. Appl. Pyrolysis 2019, 139, 250-257. [CrossRef]

17. Sambusiti, C.; Bellucci, M.; Zabaniotou, A.; Beneduce, L.; Monlau, F. Algae as promising feedstocks for fermentative biohydrogen production according to a biorefinery approach: A comprehensive review. Renew. Sustain. Energy Rev. 2015, 44, 20-36. [CrossRef]

18. Marin-Batista, J.D.; Villamil, J.A.; Rodriguez, J.J.; Mohedano, A.F.; de la Rubia, M.A. Valorization of microalgal biomass by hydrothermal carbonization and anaerobic digestion. Bioresour. Technol. 2019, 274, 395-402. [CrossRef]

19. Liu, H.; Chen, Y.; Yang, H.; Gentili, F.G.; Söderlind, U.; Wang, X.; Zhang, W.; Chen, H. Hydrothermal carbonization of natural microalgae containing a high ash content. Fuel 2019, 249, 441-448. [CrossRef]

20. Heilmann, S.M.; Davis, H.T.; Jader, L.R.; Lefebvre, P.A.; Sadowsky, M.J.; Schendel, F.J.; von Keitz, M.G.; Valentas, K.J. Hydrothermal carbonization of microalgae. Biomass Bioenergy 2010, 34, 875-882. [CrossRef]

21. Pecchi, M.; Baratieri, M. Coupling anaerobic digestion with gasification, pyrolysis or hydrothermal carbonization: A review. Renew. Sustain. Energy Rev. 2019, 105, 462-475. [CrossRef]

22. Chen, W.H.; Peng, J.; Bi, X.T. A state-of-the-art review of biomass torrefaction, densification and applications. Renew. Sustain. Energy Rev. 2015, 44, 847-866. [CrossRef] 
23. Chen, W.H.; Cheng, C.L.; Show, P.L.; Ong, H.C. Torrefaction performance prediction approached by torrefaction severity factor. Fuel 2019, 251, 126-135. [CrossRef]

24. Chen, W.H.; Lin, B.J.; Colin, B.; Chang, J.S.; Pétrissans, A.; Bi, X.; Pétrissans, M. Hygroscopic transformation of woody biomass torrefaction for carbon storage. Appl. Energy 2018, 231, 768-776. [CrossRef]

25. Arias, B.; Pevida, C.; Fermoso, J.; Plaza, M.G.; Rubiera, F.; Pis, J.J. Influence of torrefaction on the grindability and reactivity of woody biomass. Fuel Process. Technol. 2008, 89, 169-175. [CrossRef]

26. Yu, K.L.; Show, P.L.; Ong, H.C.; Ling, T.C.; Lan, J.C.-W.; Chen, W.H.; Chang, J.S. Microalgae from wastewater treatment to biochar-Feedstock preparation and conversion technologies. Energy Convers. Manag. 2017, 150, 1-13. [CrossRef]

27. Azizi, K.; Moraveji, M.K.; Najafabadi, H.A. Simultaneous pyrolysis of microalgae C. vulgaris, wood and polymer: The effect of third component addition. Bioresour. Technol. 2018, 247, 66-72. [CrossRef]

28. Chen, W.; Chen, Y.; Yang, H.; Xia, M.; Li, K.; Chen, X.; Chen, H. Co-pyrolysis of lignocellulosic biomass and microalgae: Products characteristics and interaction effect. Bioresour. Technol. 2017, 245, 860-868. [CrossRef]

29. Tang, Z.; Chen, W.; Chen, Y.; Yang, H.; Chen, H. Co-pyrolysis of microalgae and plastic: Characteristics and interaction effects. Bioresour. Technol. 2019, 274, 145-152. [CrossRef]

30. Chen, W.H.; Huang, M.Y.; Chang, J.S.; Chen, C.Y. Thermal decomposition dynamics and severity of microalgae residues in torrefaction. Bioresour. Technol. 2014, 169, 258-264. [CrossRef]

31. Chen, W.H.; Huang, M.Y.; Chang, J.S.; Chen, C.Y. Torrefaction operation and optimization of microalga residue for energy densification and utilization. Appl. Energy 2015, 154, 622-630. [CrossRef]

32. Chen, W.H.; Wu, Z.Y.; Chang, J.S. Isothermal and non-isothermal torrefaction characteristics and kinetics of microalga Scenedesmus obliquus CNW-N. Bioresour. Technol. 2014, 155, 245-251. [CrossRef]

33. He, X.M.; Pan, Y.; Li, W.; Fang, J.Q.; Wang, X.J. Study on low temperature co-carbonization of coal and algae. Adv. Mater. Res. 2012, 581, 919-923. [CrossRef]

34. Han, Y.; Hoekman, S.K.; Cui, Z.; Jena, U.; Das, P. Hydrothermal liquefaction of marine microalgae biomass using co-solvents. Algal Res. 2019, 38, 101421. [CrossRef]

35. Gai, C.; Li, Y.; Peng, N.; Fan, A.; Liu, Z. Co-liquefaction of microalgae and lignocellulosic biomass in subcritical water. Bioresour Technol. 2015, 185, 240-245. [CrossRef]

36. Gan, Y.Y.; Ong, H.C.; Show, P.L.; Ling, T.C.; Chen, W.H.; Yu, K.L.; Abdullah, R. Torrefaction of microalgal biochar as potential coal fuel and application as bio-adsorbent. Energy Convers. Manag. 2018, 165, 152-162. [CrossRef]

37. Aguado, R.; Cuevas, M.; Pérez-Villarejo, L.; Martínez-Cartas, M.L.; Sánchez, S. Upgrading almond-tree pruning as a biofuel via wet torrefaction. Renew. Energy 2020, 145, 2091-2100. [CrossRef]

38. Atallah, E.; Zeaiter, J.; Ahmad, M.N.; Leahy, J.J.; Kwapinski, W. Hydrothermal carbonization of spent mushroom compost waste compared against torrefaction and pyrolysis. Fuel Process. Technol. 2021, 216, 106795. [CrossRef]

39. Schmid, D.; Karlström, O.; Yrjas, P. Release of NH3, HCN and NO during devolatilization and combustion of washed and torrefied biomass. Fuel 2020, 280, 118583. [CrossRef]

40. Huang, Y.; Lo, S. Predicting heating value of lignocellulosic biomass based on elemental analysis. Energy 2020, $191,116501$. [CrossRef]

41. Şen, A.U.; Nobre, C.; Durão, L.; Miranda, I.; Pereira, H.; Gonçalves, M. Low-temperature biochars from cork-rich and phloem-rich wastes: Fuel, leaching, and methylene blue adsorption properties. Biomass Convers. Biorefin. 2020. [CrossRef]

42. Parikh, J.; Channiwala, S.A.; Ghosal, G.K. A correlation for calculating HHV from proximate analysis of solid fuels. Fuel 2005, 84, 487-494. [CrossRef]

43. Singleton, V.L.; Orthofer, R.; Lamuela-Raventós, R.M. Analysis of total phenols and other oxidation substrates and antioxidants by means of folin-ciocalteu reagent. Methods Enzymol. 1999, 299, 152-178.

44. Miller, G.L. Use of dinitrosalicylic acid reagent for determination of reducing sugar. Anal. Chem. 1959, 31, 426-428. [CrossRef]

45. Nobre, C.; Vilarinho, C.; Alves, O.; Mendes, B.; Gonçalves, M. Upgrading of refuse derived fuel through torrefaction and carbonization: Evaluation of RDF char fuel properties. Energy 2019, 181, 66-76. [CrossRef]

46. Artan, A.; Acquah, C.; Danquah, M.K. Process Analysis of Microalgae Biomass Thermal Disruption for Biofuel Production. In Advances in Bioprocess Technology; Ravindra, P., Ed.; Springer International Publishing: Cham, Switzerland, 2015 ; pp. 113-131. ISBN 9783319179155. [CrossRef]

47. Ohliger, A.; Förster, M.; Kneer, R. Torrefaction of beechwood: A parametric study including heat of reaction and grindability. Fuel 2013, 104, 607-613. [CrossRef]

48. Correia, R.; Gonçalves, M.; Nobre, C.; Mendes, B. Impact of torrefaction and low-temperature carbonization on the properties of biomass wastes from Arundo donax L. and Phoenix canariensis. Bioresour. Technol. 2017, 223, 210-218. [CrossRef] [PubMed]

49. Han, F.Y.; Komiyama, M.; Uemura, Y.; Rabat, N.E. One-path catalytic supercritical methanothermal production of fatty acid methyl ester fractions from wet microalgae Chlorella vulgaris. Biomass Bioenergy 2020, 143, 105834. [CrossRef]

50. Mao, Q.; Rajabpour, S.; Kowalik, M.; van Duin, A.C.T. Predicting cost-effective carbon fiber precursors: Unraveling the functionalities of oxygen and nitrogen-containing groups during carbonization from ReaxFF simulations. Carbon N. Y. 2020, 159, 25-36. [CrossRef]

51. Zhang, C.; Ho, S.H.; Chen, W.H.; Xie, Y.; Liu, Z.; Chang, J.S. Torrefaction performance and energy usage of biomass wastes and their correlations with torrefaction severity index. Appl. Energy 2018, 220, 598-604. [CrossRef] 
52. Barskov, S.; Zappi, M.; Buchireddy, P.; Dufreche, S.; Guillory, J.; Gang, D.; Hernandez, R.; Bajpai, R.; Baudier, J.; Cooper, R.; et al. Torrefaction of biomass: A review of production methods for biocoal from cultured and waste lignocellulosic feedstocks. Renew. Energy 2019, 142, 624-642. [CrossRef]

53. Cao, Y.; He, M.; Dutta, S.; Luo, G.; Zhang, S.; Daniel, C.; Tsang, W. Hydrothermal carbonization and liquefaction for sustainable production of hydrochar and aromatics. Renew. Sustain. Energy Rev. 2021, 152, 111722. [CrossRef]

54. Feng, Y.; Qiu, K.; Zhang, Z.; Li, C.; Rahman, M.M.; Cai, J. Distributed Activation Energy Model for Lignocellulosic Biomass Torrefaction Kinetics with Combined Heating Program. Energy 2021, 239, 122228. [CrossRef]

55. Nobre, C.; Dinis, T.T.; Gonçalves, M.; Vilarinho, C. Using torrefied biomass wastes as low-cost adsorbents for methylene blue. In Proceedings of the 3rd International Congress on Water, Waste and Energy, Rome, Italy, 18-20 July 2016; p. 499.

56. Binda, G.; Spanu, D.; Bettinetti, R.; Magagnin, L.; Pozzi, A.; Dossi, C. Comprehensive comparison of microalgae-derived biochar from different feedstocks: A prospective study for future environmental applications. Algal Res. 2020, 52, 102103. [CrossRef]

57. Landin-Sandoval, V.J.; Mendoza-Castillo, D.I.; Seliem, M.K.; Mobarak, M.; Villanueva-Mejia, F.; Bonilla-Petriciolet, A.; NavarroSantos, P.; Reynel-Ávila, H.E. Physicochemical analysis of multilayer adsorption mechanism of anionic dyes on lignocellulosic biomasses via statistical physics and density functional theory. J. Mol. Liq. 2021, 322, 114511. [CrossRef]

58. Huang, C.; Liao, H.; Ma, X.; Xiao, M.; Liu, X.; Gong, S.; Shu, X.; Zhou, X. Adsorption performance of chitosan Schiff base towards anionic dyes: Electrostatic interaction effects. Chem. Phys. Lett. 2021, 780, 138958. [CrossRef]

59. Lashaki, M.J.; Atkinson, J.D.; Hashisho, Z.; Phillips, J.H.; Anderson, J.E.; Nichols, M. The role of beaded activated carbon's pore size distribution on heel formation during cyclic adsorption/desorption of organic vapors. J. Hazard. Mater. 2016, $315,42-51$. [CrossRef]

60. Jagodzińska, K.; Czerep, M.; Kudlek, E.; Wnukowski, M.; Yang, W. Torrefaction of wheat-barley straw: Composition and toxicity of torrefaction condensates. Biomass Bioenergy 2019, 129, 105335. [CrossRef]

61. Cahyanti, M.N.; Doddapaneni, T.R.K.C.; Kikas, T. Biomass torrefaction: An overview on process parameters, economic and environmental aspects and recent advancements. Bioresour. Technol. 2020, 301, 122737. [CrossRef]

62. Grewal, A.; Abbey, L.; Gunupuru, L.R. Production, prospects and potential application of pyroligneous acid in agriculture. J. Anal. Appl. Pyrolysis 2018, 135, 152-159. [CrossRef]

63. Frolov, S.M.; Smetanyuk, V.A.; Shamshin, I.O.; Sadykov, I.A.; Koval', A.S.; Frolov, F.S. Production of highly superheated steam by cyclic detonations of propane- and methane-steam mixtures with oxygen for waste gasification. Appl. Therm. Eng. 2021, 183, 116195. [CrossRef]

64. Azwar, E.; Chan, D.J.C.; Kasan, N.A.; Rastegari, H.; Yang, Y.; Sonne, C.; Tabatabaei, M.; Aghbashlo, M.; Lam, S.S. A comparative study on physicochemical properties, pyrolytic behaviour and kinetic parameters of environmentally harmful aquatic weeds for sustainable shellfish aquaculture. J. Hazard. Mater. 2022, 424, 127329. [CrossRef]

65. Sun, M.C.; Yuan, X.H.; Luo, Z.J.; Zhu, X.F. Influence of heating temperatures on the component distribution of distillates derived from walnut shell bio-oil. J. Fuel Chem. Technol. 2020, 48, 1179-1185. [CrossRef]

66. Zhang, C.; Wang, C.; Cao, G.; Chen, W.H.; Ho, S.H. Comparison and characterization of property variation of microalgal biomass with non-oxidative and oxidative torrefaction. Fuel 2019, 246, 375-385. [CrossRef]

67. Sermyagina, E.; Saari, J.; Zakeri, B.; Kaikko, J.; Vakkilainen, E. Effect of heat integration method and torrefaction temperature on the performance of an integrated CHP-torrefaction plant. Appl. Energy 2015, 149, 24-34. [CrossRef]

68. Delrue, F. Techno-Economic Analysis of Microalgae And Algal Biofuel Production (As A Tool For Driving R\&D Efforts). In Green Chemistry for Sustainable Biofuel Production; Gude, V.G., Ed.; Apple Academic Press: Boca Raton, FL, USA, 2018 ; p. 22.

69. Wibawa, D.S.; Nasution, M.A.; Noguchi, R.; Ahamed, T.; Demura, M.; Watanabe, M.M. Microalgae oil production: A downstream approach to energy requirements for the minamisoma pilot plant. Energies 2018, 11, 521. [CrossRef]

70. Igwegbe, C.A.; Mohmmadi, L.; Ahmadi, S.; Rahdar, A.; Khadkhodaiy, D.; Dehghani, R.; Rahdar, S. Modeling of adsorption of Methylene Blue dye on Ho-CaWO4 nanoparticles using Response Surface Methodology (RSM) and Artificial Neural Network (ANN) techniques. MethodsX 2019, 6, 1779-1797. [CrossRef]

71. Hernández-García, A.; Velásquez-Orta, S.B.; Novelo, E.; Yáñez-Noguez, I.; Monje-Ramírez, I.; Ledesma, M.T.O. Wastewaterleachate treatment by microalgae: Biomass, carbohydrate and lipid production. Ecotoxicol. Environ. Saf. 2019, 174, 435-444. [CrossRef]

72. Fakayode, O.A.; Aboagarib, E.A.A.; Zhou, C.; Ma, H. Co-pyrolysis of lignocellulosic and macroalgae biomasses for the production of biochar-A review. Bioresour. Technol. 2020, 297, 122408. [CrossRef]

73. Wang, K.; Brown, R.C.; Homsy, S.; Martinez, L.; Sidhu, S.S. Fast pyrolysis of microalgae remnants in a fluidized bed reactor for bio-oil and biochar production. Bioresour. Technol. 2013, 127, 494-499. [CrossRef] 